Prepared in cooperation with the National Park Service and the Bureau of Land Management

\title{
Geologic Map of the North Half of the Lake Walcott 30 '×60' Quadrangle, Idaho
}
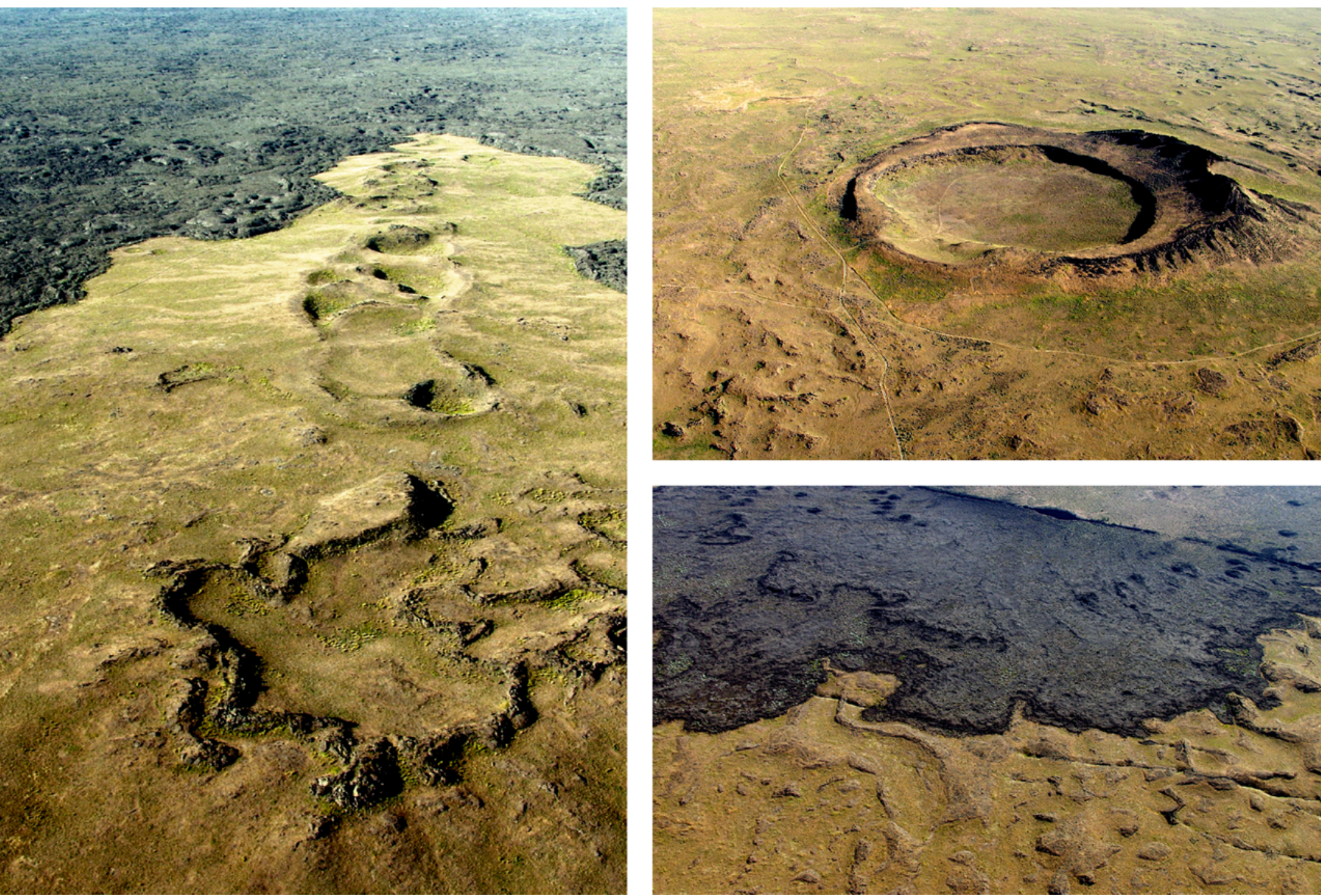

Pamphlet to accompany

Scientific Investigations Map 3405

U.S. Department of the Interior

U.S. Geological Survey

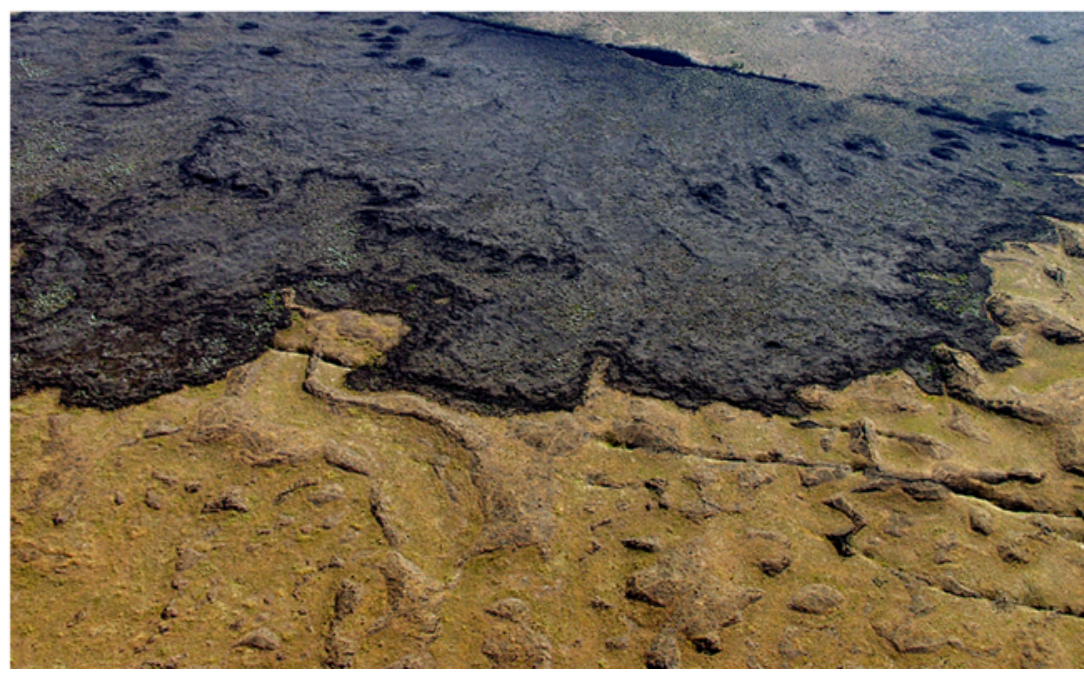




\section{Cover Photographs.}

Left-Vent area for Wapi Park lava field. Photograph taken July 11, 2002.

Top right—Split Butte. Photograph taken July 15, 2004.

Bottom right—Kings Bowl lava field. Photograph taken July 11, 2002. Photographs by Susan Sakimoto (Space Science Institute and University at Buffalo) and Scott Hughes, pilot (Dept. of Geosciences Idaho State University). Used with permission. 


\section{Geologic Map of the North Half of the Lake Walcott 30'×60' Quadrangle, Idaho}

By Mel A. Kuntz, Duane E. Champion, Brent R. Turrin, Phillip B. Gans, Harry R. Covington, and D. Paco VanSistine

Prepared in cooperation with the National Park Service and the Bureau of Land Management

Pamphlet to accompany

Scientific Investigations Map 3405 


\title{
U.S. Department of the Interior \\ RYAN K. ZINKE, Secretary
}

\author{
U.S. Geological Survey \\ James F. Reilly II, Director
}

U.S. Geological Survey, Reston, Virginia: 2018

For more information on the USGS - the Federal source for science about the Earth, its natural and living resources, natural hazards, and the environment-visit https://www.usgs.gov or call 1-888-ASK-USGS.

For an overview of USGS information products, including maps, imagery, and publications,

visit https://store.usgs.gov.

Any use of trade, firm, or product names is for descriptive purposes only and does not imply endorsement by the U.S. Government.

Although this information product, for the most part, is in the public domain, it also may contain copyrighted materials as noted in the text. Permission to reproduce copyrighted items must be secured from the copyright owner.

Suggested citation:

Kuntz, M.A., Champion, D.E., Turrin, B.R., Gans, P.B., Covington, H.R., and VanSistine, D.P., 2018, Geologic map of the north half of the Lake Walcott 30'x60' quadrangle, Idaho: U.S. Geological Survey Scientific Investigations Report 3405, pamphlet 25 p., scale 1:100,000, https://doi.org/10.3133/sim3405.

ScienceBase data release GIS and other files that support this report are available at https://doi.org/10.5066/F7V030VZ

ISSN 2329-132X (online) 


\section{Contents}

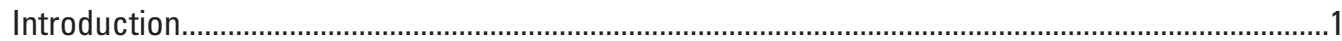

Pleistocene and Holocene Basaltic Volcanism in the Eastern Snake River Plain and the

Area of this Map ...................................................................................................

Evolution, Purpose, and Use of this Map ...................................................................................

Rock Nomenclature, Petrologic Descriptions, and Notes on Rock Names, Descriptions, and

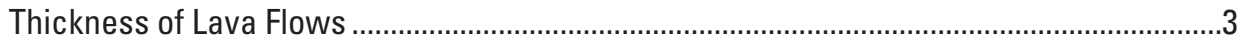

Notes on Names and Unit Labels Given to Lava Fields in this Map.......................................3

Subdivisions of Holocene and Pleistocene Time Used for Basaltic Lava Fields

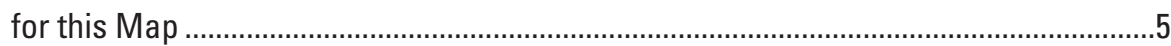

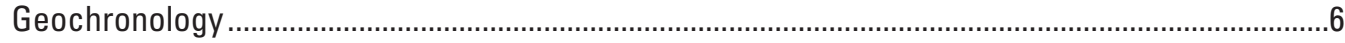

Radiocarbon Ages of Lava Flows of the Craters of the Moon Lava Field ................................6

${ }^{40} \mathrm{Ar} /{ }^{39} \mathrm{Ar}$ Studies of Basaltic Lava Fields in the North Half of the Lake Walcott $30^{\prime} \times 60^{\prime}$ Quadrangle .........................................................................................................

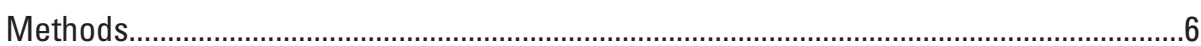

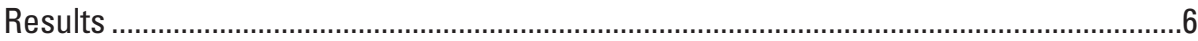

Whole-Rock Potassium-Argon Studies and Results ............................................................

Paleomagnetic Studies ......................................................................................................

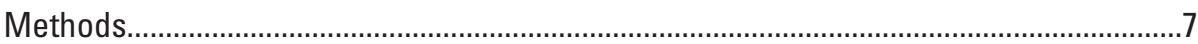

Results and Interpretations .................................................................................

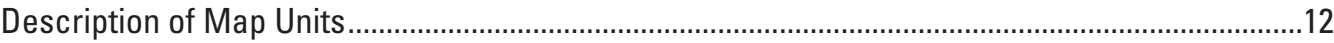

Unconsolidated Surficial Deposits .....................................................................................12

Holocene and Pleistocene Basaltic Lava Flows and Related Near-Vent Pyroclastic and

Eruptive-Fissure Deposits of the Snake River Group ................................................12

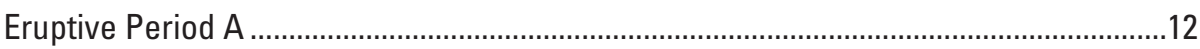

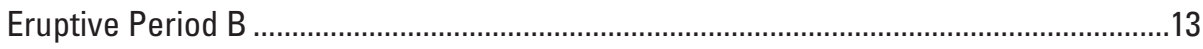

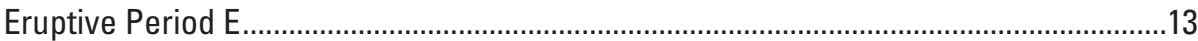

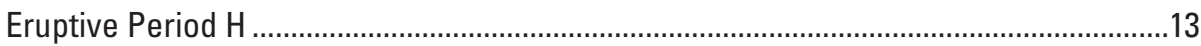

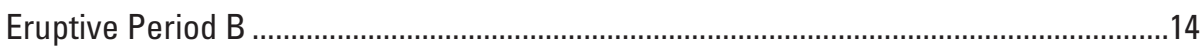

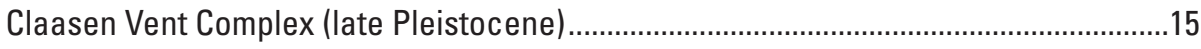

Inferno Chasm Vent Complex (late Pleistocene) ............................................................16

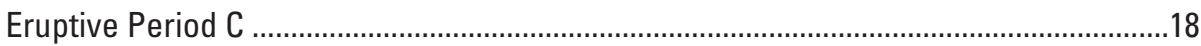

Flat Top Vent Complex (late middle Pleistocene)..........................................................19

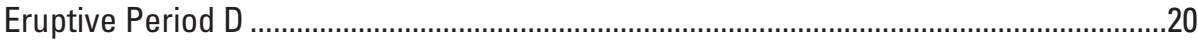

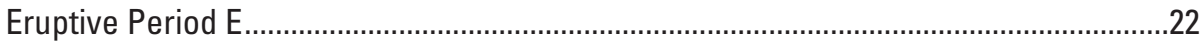

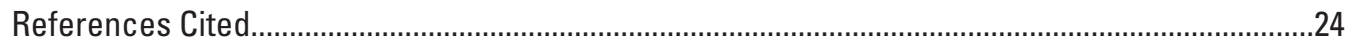




\section{Figures}

1. Regional index map with the location of the study area and showing prominent features .1

2. Craters of the Moon National Park and Preserve administrative boundaries with U.S. Geological Survey quadrangles.

3. Digital orthophotograph of the Craters of the Moon, Kings Bowl, and Wapi lava fields showing the location of the Craters of the Moon $30^{\prime} \times 60^{\prime}$ quadrangle and the north half of the Lake Walcott $30^{\prime} \times 60^{\prime}$ quadrangle

\section{Tables}

1. ${ }^{40} \mathrm{Ar} /{ }^{39} \mathrm{Ar}$ and $\mathrm{K}-\mathrm{Ar}$ ages for basaltic lava fields on or extending into the north half of the Lake Walcott 30 '×60' quadrangle, Idaho.....

2. Paleomagnetic data for the north half of the Lake Walcott $30^{\prime} \times 60^{\prime}$ quadrangle, Idaho ...8 


\section{Conversion Factors}

International System of Units to U.S. customary units

\begin{tabular}{lll}
\hline \multicolumn{1}{c}{ Multiply } & By & \multicolumn{1}{c}{ To obtain } \\
\hline millimeter $(\mathrm{mm})$ & Length & \\
meter $(\mathrm{m})$ & 0.03937 & inch (in.) \\
kilometer $(\mathrm{km})$ & 3.281 & foot (ft) \\
\hline square kilometer $\left(\mathrm{km}^{2}\right)$ & 0.6214 & mile (mi) \\
\hline & Area & \\
\hline cubic kilometer $\left(\mathrm{km}^{3}\right)$ & 0.3861 & square mile $\left(\mathrm{mi}^{2}\right)$ \\
\hline
\end{tabular}

Temperature in degrees Celsius $\left({ }^{\circ} \mathrm{C}\right)$ may be converted to degrees Fahrenheit $\left({ }^{\circ} \mathrm{F}\right)$ as

$$
{ }^{\circ} \mathrm{F}=\left(1.8 \times{ }^{\circ} \mathrm{C}\right)+32 \text {. }
$$

Temperature in degrees Fahrenheit $\left({ }^{\circ} \mathrm{F}\right)$ may be converted to degrees Celsius $\left({ }^{\circ} \mathrm{C}\right)$ as

$$
{ }^{\circ} \mathrm{C}=\left({ }^{\circ} \mathrm{F}-32\right) / 1.8 \text {. }
$$

\section{Datum}

Vertical coordinate information is referenced to the North American Vertical Datum of 1929 (NAVD 29).

Horizontal coordinate information is referenced to the North American Datum of 1927(NAD 27).

Altitude, as used in this report, refers to distance above the vertical datum.

\section{Divisions of Quaternary, Neogene, and Paleogene time

\begin{tabular}{|c|c|c|c|}
\hline $\begin{array}{l}\text { Period or } \\
\text { subperiod }\end{array}$ & Epoch & & $\begin{array}{c}\text { Age } \\
\text { (sidereal years) }\end{array}$ \\
\hline \multirow{5}{*}{ Quaternary } & Holocene & & $0-11.7 \mathrm{ka}$ \\
\hline & \multirow{4}{*}{ Pleistocene } & late & $11.7-128 \mathrm{ka}$ \\
\hline & & late middle & $128-400 \mathrm{ka}$ \\
\hline & & early middle & $400-780 \mathrm{ka}$ \\
\hline & & early & $780 \mathrm{ka}-1.8 \mathrm{Ma}$ \\
\hline
\end{tabular} used in this report ${ }^{1}$}

${ }^{1}$ Ages of time boundaries are those of the U.S. Geological Survey Geologic Names Committee (2010) except those for the Pleistocene. Age boundaries for the Pleistocene are as defined by the authors for the purposes of this report. Ages are expressed in in ka for kilo-annum (thousand years), and Ma for megaannum (million years). Yr B.P., years before present (before A.D. 1950) 



\title{
Geologic Map of the North Half of the Lake Walcott 30'×60' Quadrangle, Idaho
}

\author{
By Mel A. Kuntz, ${ }^{1}$ Duane E. Champion, ${ }^{1}$ Brent R. Turrin, ${ }^{2}$ Phillip B. Gans, ${ }^{3}$ Harry R. Covington, ${ }^{1}$ and \\ D. Paco VanSistine ${ }^{1}$
}

\section{Introduction}

\section{Pleistocene and Holocene Basaltic Volcanism in the Eastern Snake River Plain and the Area of this Map}

This map depicts the volcanic geology of the north half of the U.S. Geological Survey (USGS) Lake Walcott 30'×60' quadrangle in the Snake River Plain in southern Idaho. The map also contains a part of the Craters of the Moon National Monument and Preserve (fig. 1). The Great Rift volcanic rift zone is present here; an 85-kilometer (km)-long, 2- to $15-\mathrm{km}$ wide belt of lava fields of various sizes, tephra cones, lava cones, shield volcanoes, eruptive fissures and associated tephra deposits, and non-eruptive fissures. Basaltic volcanism was a dominant geologic process in the eastern Snake River Plain in Holocene time, as attested by eight dominantly Holocene $(<15$ thousand year old [ka]) lava fields covering about 13 percent of the eastern Snake River Plain (Kuntz and others, 1992). Three of the lava fields, Craters of the Moon, Kings Bowl, and Wapi, are located along the Great Rift volcanic rift zone. The Wapi and Kings Bowl lava fields are depicted in this map. The Craters of the Moon lava field and associated structures along the Great Rift volcanic rift zone are depicted in the geologic map of the Craters of the Moon 30' $\times 60^{\prime}$ quadrangle, Idaho (Kuntz and others, 2007).

President Coolidge established the Craters of the Moon National Monument on May 2, 1924. Since 1924, the Monument has been expanded through five presidential proclamations. The most recent and largest expansion of the Monument occurred November 9, 2000, when President Clinton signed a proclamation enlarging the Monument 13-fold, from 222 square kilometers $\left(\mathrm{km}^{2}\right)$ that was managed as Craters of the Moon National Monument, to $2,893 \mathrm{~km}^{2}$ and now includes lands managed by the Bureau of Land Management (BLM) and the National Park Service as the Craters of the Moon National Monument and Preserve (fig. 2). The expanded Monument and Preserve encompasses the entire Great Rift volcanic rift zone and the entire Craters of the Moon, Wapi, and Kings Bowl lava fields and most of the Horse Butte-Bear Trap lava-tube system (Kuntz and others, 2007).

The Geographic Information System (GIS) data and related data files are available as a USGS data release in ScienceBase at https://doi.org/10.5066/F7VQ30VZ (Kuntz and VanSistine, 2018)

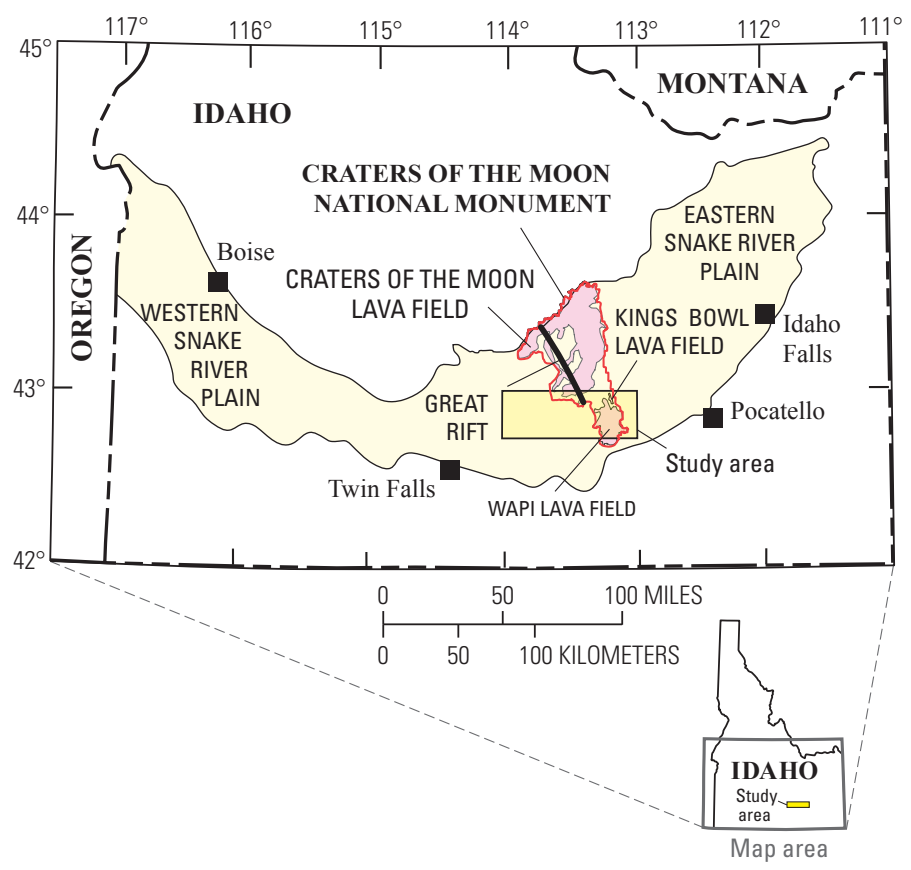

Figure 1. Regional index map with the location of the study area and showing prominent features. Modified from Kuntz and others (2007). Yellow area is the Snake River Plain.

${ }^{1}$ U.S. Geological Survey

${ }^{2}$ Department of Earth and Planetary Sciences, Rutgers University, Piscataway, N.J.

${ }^{3}$ Department of Earth Science, University of California, Santa Barbara, Calif. 


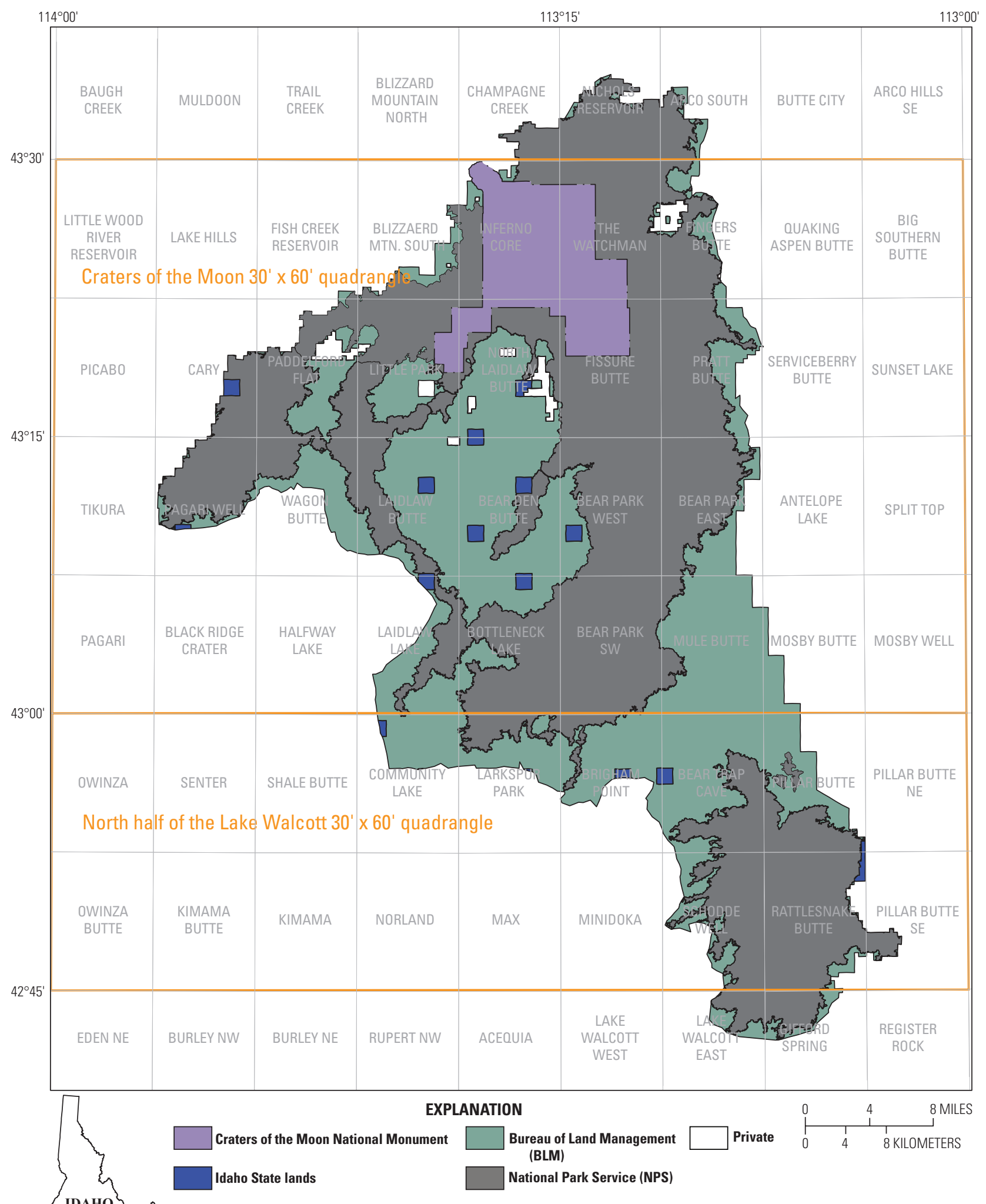

Figure 2. Craters of the Moon National Park and Preserve administrative boundaries with U.S. Geological Survey 7.5 quadrangles. In 2000, a proclamation was signed enlarging the monument from 222 square kilometers $\left(\mathrm{km}^{2}\right.$, purple area) to now include lands managed by the Bureau of Land Management and the National Park Service as the Craters of the Moon National Monument and Preserve for a total of 2,893 $\mathrm{km}^{2}$ (green and gray areas, respectively). Figure modified from National Park Service quadrangle map accessed on October 25, 2017, at https://www.nps.gov/crmo/ planyourvisit/upload/quads.pdf. 


\section{Evolution, Purpose, and Use of this Map}

With the expansion of the Craters of the Moon National Monument and Preserve, funds became available from the National Park Service (NPS) and the U.S. Bureau of Land Management (BLM). This funding enabled the completion of geologic mapping, detailed paleomagnetic studies, and ${ }^{40} \mathrm{Ar} /{ }^{39} \mathrm{Ar}$ dating of the pre-Holocene lava fields of the northern part of the USGS Lake Walcott quadrangle.

A preliminary geologic map in the area of the Wapi and Kings Bowl lava fields produced by Covington (1977) provided details of the geology of that area.

The distal parts of the Craters of the Moon lava field extend southward into the Lake Walcott quadrangle; thus, some of the field, paleomagnetic, radiocarbon, and ${ }^{40} \mathrm{Ar} /{ }^{39} \mathrm{Ar}$ data from Kuntz and others (2007) have been incorporated in this geologic map (fig. 3). These data give additional details of the volcanic history of the Holocene lava fields along the Great Rift volcanic rift zone, and older lava fields and their vent complexes near the Great Rift and nearby areas in the Lake Walcott quadrangle. For vent complexes, a half dozen or so vents are aerially contiguous and distributed in a seemingly random spatial pattern, but paleomagnetic data for the vents are identical, suggesting that these vents erupted simultaneously or within a short span of time ( $<100$ years). Kuntz and others (2007) noted that the radiocarbon and ${ }^{40} \mathrm{Ar} /{ }^{39} \mathrm{Ar}$ data enabled a detailed analysis of the time scales of basaltic volcanism along the Great Rift volcanic rift zone in the geologic map of the Craters of the Moon $30^{\prime} \times 60^{\prime}$ quadrangle. The additional radiocarbon and ${ }^{40} \mathrm{Ar} /{ }^{39} \mathrm{Ar}$ data depicted on this map can be used to determine the "pulse rate" for basaltic volcanism for the entire length of the Great Rift volcanic rift zone and for a very large area that spans nearly the entire width of the eastern Snake River Plain.

In addition to the pulse rate, the geologic mapping, paleomagnetic, and geochronologic studies of the north half of the Lake Walcott quadrangle have provided detail about additional volcanic rift zones in the map area. A volcanic rift zone parallel to (about N. $10^{\circ} \mathrm{W}$.) but approximately 2.5 $\mathrm{km}$ east of the Great Rift volcanic rift zone includes vents at Horse Butte (Qsbb25), Cottrells Blowout (Qwfb14), Inferno Chasm (Qwfb12), and Grandview Crater (Qwfb3). Eruptions from the first three vents occurred about $73 \pm 8 \mathrm{ka}$; eruptions from Grandview Crater occurred about $38 \pm 12 \mathrm{ka}$ (table 1). This volcanic rift zone has previously been called the "Inferno Chasm" volcanic rift zone (Greeley, 1982). Another volcanic rift zone, having an orientation of N.15 ${ }^{\circ}$ E., is defined by the vents of Wapi Park, a kipuka vent in the Wapi lava field about $4 \mathrm{~km}$ southwest of Pillar Butte, and the Higgins Blowout along the southwest margin of the Wapi lava field. ${ }^{40} \mathrm{Ar} /{ }^{39} \mathrm{Ar}$ ages along this volcanic rift zone are $87 \pm 9 \mathrm{ka}$ for the Wapi Park lava field (Qwfb15) and 289 5 ka (Qwfc3) for the Higgins Blowout lava field (table 1), indicating a long eruptive history. The young ( $19 \pm 2 \mathrm{ka}$; table 1$)$ Shale Butte lava field (Qwfb1) lies on a southward extension of the Borkum Rift volcanic rift zone in the Craters of the Moon quadrangle that includes north-south-aligned vents at Sand Butte (Qsbb6; 34 $\pm 29 \mathrm{ka}$ ) (table 1) and Broken Top Butte (<50 ka) (Kuntz and others, 2007).

\section{Rock Nomenclature, Petrologic Descriptions, and Notes on Rock Names, Descriptions, and Thickness of Lava Flows}

The chemical and petrographic classification of lava fields in the eastern Snake River Plain and the Craters of the Moon lava field can be found in Kuntz and others (1992), Kuntz and others (2007), and Putirka and others (2009). Detailed chemical analyses of rocks and petrographic studies of the lava flows were not completed for the north half of the Lake Walcott quadrangle area due to project priorities. We therefore classify lava fields of the north half of the Lake Walcott quadrangle as simply "basaltic" rocks.

In the map area, there is little if any erosion of lava flows, thus the thickness of buried lava flows is not revealed through any erosional remnants. In addition, there are few logged core holes within the map area for which the thickness of lava flows may be determined. For these reasons, thickness of lava flows and lava fields are not given in the Description of Map Units. However, from the study of core holes at the Idaho National Laboratory (INL), it has been determined that pahoehoe flows average about $20 \mathrm{~m}$ thick and a'a flows are typically 15-30 m thick (Kuntz, Champion, and others, 1986; Champion and others, 2002). From the analysis of topographic maps, it can be determined that lava flows may accumulate to thicknesses of as much as $200 \mathrm{~m}$ around a vent and on top of underlying flows. However, a more common thickness of flows in vent areas is about $30-50 \mathrm{~m}$. The area of individual lava fields given in the Description of Map Units was determined from USGS 1:24,000-scale topographic maps. Volumes of lava fields were estimated assuming the lava field has the shape of a cone. The basal area of the cone is equal to the lava-field area and the height of the cone as determined from the topographic maps.

\section{Notes on Names and Unit Labels Given to Lava Fields in this Map}

A discussion of the naming of lava flows of the Craters of the Moon lava field, some of which flow into the northern part of this map, is given in Kuntz and others (2007). The map unit labels for those lava flows of the Craters of the Moon lava field that are present in the northern part of this map are retained for this map. For Craters of the Moon flows, "Q" refers to Quaternary age, and the second letter, "c," references flows of the Craters of the Moon lava field. The third letter, for example, "f," refers to the type of deposit (f, flow), and 


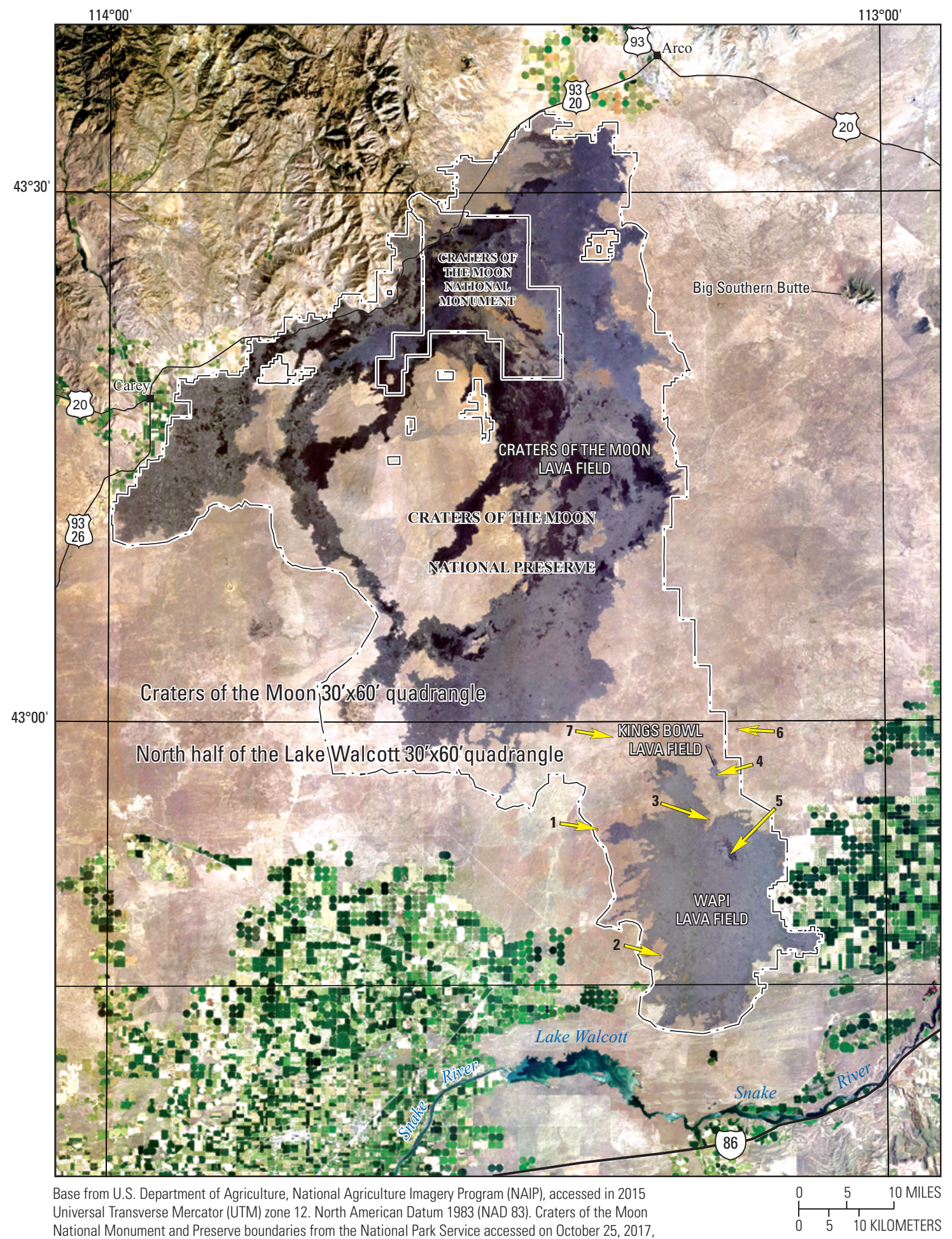

at https://catalog.data.gov/dataset/administrative-boundaries-

of-national-park-system-units-9-30-2017-national-geospatial-data.

Figure 3. Digital orthophotograph of the Craters of the Moon, Kings Bowl, and Wapi lava fields showing the location of the Craters of the Moon $30^{\prime} \times 60^{\prime}$ quadrangle and the north half of the Lake Walcott $30^{\prime} \times 60^{\prime}$ quadrangle. Yellow arrows indicate the locations of photographs of selected features: 1, Split Butte; 2, Higgins Blowout; 3, Wapi Park; 4, Kings Bowl; 5, Pillar Butte; 6, Cottrells Blowout; 7, Bear Trap cave. 
Table 1. ${ }^{40} \mathrm{Ar} /{ }^{39} \mathrm{Ar}$ and $\mathrm{K} / \mathrm{Ar}$ ages for basaltic lava fields on or extending into the North Half of the Lake Walcott $30^{\prime} \times 60^{\prime}$ quadrangle, Idaho.

${ }^{40} \mathrm{Ar} /{ }^{39} \mathrm{Ar}$ data for basaltic lava fields of the Snake River Group

[--, indicates no data; ka, age in thousands of years. Analytical laboratories: UCSB, University of California at Santa Barbara, Santa Barbara, Calif., Dr. Phil Gans; RU, Rutgers University, Dr. Brent Turrin; DEN, U.S. Geogical Survey, Denver, Colo., Dr. Dan Miggins. All errors given for our estimated (preferred) ages, as reported throughout the text and here, are \pm 1 one sigma $(\sigma)]$

\begin{tabular}{|c|c|c|c|c|c|c|c|}
\hline Geographic location & $\begin{array}{l}\text { Analytical } \\
\text { Laboratory }\end{array}$ & $\begin{array}{c}\text { Field } \\
\text { number }\end{array}$ & $\begin{array}{l}\text { Weighted } \\
\text { mean plateau } \\
\text { age (ka) }\end{array}$ & $\begin{array}{l}\text { Isochron } \\
\text { age (ka) }\end{array}$ & $\begin{array}{c}\text { Total } \\
\text { fusion } \\
\text { age (ka) }\end{array}$ & $\begin{array}{c}\text { Preferred } \\
\text { age }( \pm 1 \sigma) \text { ka }\end{array}$ & $\begin{array}{c}\text { Map } \\
\text { unit } \\
\text { symbol }\end{array}$ \\
\hline Shale Butte & UCSB & $03 \mathrm{~K} 45$ & $11 \pm 6$ & $1 \pm 1$ & $2 \pm 7$ & $\sim 19$ & Qwfb1 \\
\hline Grandview Crater & UCSB & $03 \mathrm{~K} 19$ & $38 \pm 12$ & $25 \pm 28$ & $29 \pm 11$ & $38 \pm 12$ & Qwfb3 \\
\hline West Wildhorse Butte ${ }^{1}$ & UCSB & SRP-105 & -- & -- & -- & $<50$ & Qsbb8 \\
\hline Wapi Park vent and lava-tube system & UCSB & $03 \mathrm{~K} 18$ & $87 \pm 9$ & $53 \pm 19$ & $64 \pm 11$ & $87 \pm 9$ & Qwfb15 \\
\hline Kimama Butte & RU & $03 \mathrm{~K} 50$ & $87 \pm 11$ & $70 \pm 20$ & $43 \pm 19$ & $87 \pm 11$ & Qwfb17 \\
\hline Split Butte & UCSB & $03 \mathrm{~K} 26$ & $138 \pm 6$ & $145 \pm 13$ & $122 \pm 7$ & $138 \pm 6$ & Qwfc1 \\
\hline Higgins Blowout & DEN & $03 \mathrm{~K} 51$ & $300 \pm 60$ & $289 \pm 5$ & -- & $289 \pm 5$ & Qwfc3 \\
\hline
\end{tabular}

\section{K-Ar data}

$\left[\mathrm{K}_{2} \mathrm{O}\right.$, potassium oxide; ${ }^{40} \mathrm{Ar}$ rad, ${ }^{40} \mathrm{Ar}$ radiogenic; mol/g, moles per gram; ka, age in thousands of years. Analytical laboratories: Menlo Park, U.S. Geological Survey laboratory located in Menlo Park, Calif. Analyses by M.A. Kuntz, G.Brent Dalrymple, and J.C. von Essen, and $\mathrm{K}_{2} \mathrm{O}$ analyses by S.T. Prebble are mean and standard deviation of four measurements]

\begin{tabular}{|c|c|c|c|c|c|c|c|}
\hline Geographic location & $\begin{array}{l}\text { Analytical } \\
\text { Laboratory }\end{array}$ & $\begin{array}{c}\text { Field } \\
\text { number }\end{array}$ & $\begin{array}{l}\mathrm{K}_{2} \mathrm{O} \text { weight } \\
\text { percent }\end{array}$ & $\begin{array}{c}{ }^{40} \mathrm{Ar}_{\mathrm{rad}} \\
\left(10^{-13} \mathrm{~mol} / \mathrm{g}\right)\end{array}$ & $\begin{array}{l}{ }^{40} \mathrm{Ar}_{\text {rad }} \\
\text { (percent) }\end{array}$ & $\begin{array}{l}\text { Calculated } \\
\text { age (ka) }\end{array}$ & $\begin{array}{c}\text { Map } \\
\text { unit } \\
\text { symbol }\end{array}$ \\
\hline
\end{tabular}

the fourth letter refers to the eruptive period (A through $\mathrm{H}$ ). The last number refers to the stratigraphic order of deposits assigned to an eruptive period.

For lava fields in this map, a slightly different scheme for unit labels has been employed. The descriptive names for some of the lava fields on this map are taken from prominent named vents and buttes and spot elevations near vents, as they appear on USGS 1:24,000-scale topographic map quadrangles that cover parts of this map. In the absence of named landmarks, spot elevations, mostly at high points at vents or nearby buttes, are used to identify various basaltic lava fields. The map unit symbols, as they appear in the Description of Map Units and on the map, consist of letters and numbers arranged in the following system: "Q" refers to the general age (Quaternary) of the unit. The second letter "w" refers to flows that have source vents within the north half of the Lake Walcott quadrangle. The third letter "f" refers to lava flows. The fourth letter, for example, "b" refers to arbitrary subdivisions of Pleistocene time, as described in the subsequent section. The number suffix identifies lava fields in lava-field age units, based on radiometric and stratigraphic data where available. However, because radiometric ages are available for only a few lava fields, the numbers do not imply absolute age relations of lava fields.

\section{Subdivisions of Holocene and Pleistocene Time Used for Basaltic Lava Fields for this Map}

For the purposes of this map, Holocene time is the period from the present to $10,000{ }^{14} \mathrm{C}$ yr or 11,700 calibrated or sidereal yr (USGS, 2010). The Kimama flow of the Craters of the Moon Lava field, having a radiocarbon age of $15,100 \pm 160{ }^{14} \mathrm{C}$ yr (Kuntz, Spiker, and others, 1986), is included in the age class "predominantly Holocene" used in the Craters of the Moon quadrangle (Kuntz and others, 2007). For two Holocene lava fields in this map (Kings Bowl 
[Qwfa1] and Wapi [Qwfa2]), the first four letters of their unit labels are "Qwfa." Lava fields having radiometric or stratigraphically assumed ages between $11,680{ }^{14} \mathrm{C}$ yr and 128,000 sidereal $\mathrm{yr}$ are designated late Pleistocene in age, the first four letters of their unit labels are "Qwfb." Lava fields having radiometric ages or stratigraphically assumed ages between 128,000 and 400,000 sidereal years are designated as late middle Pleistocene in age; the first four letters of their unit labels are "Qwfc." Lava fields having radiometric ages or stratigraphically assumed ages between 400,000 and 780,000 sidereal yr are designated as early middle Pleistocene in age; the first four letters of their unit labels are "Qwfd." Lava fields having radiometric ages greater than 780,000 sidereal yr and reversed magnetic polarity are designated as early Pleistocene in age; the first four letters of their unit labels are "Qwfe."

\section{Geochronology}

\section{Radiocarbon Ages of Lava Flows of the Craters of the Moon Lava Field}

Radiocarbon dating has been used to delineate the evolution of the Holocene Craters of the Moon lava field. Those data are summarized in Kuntz, Spiker, and others (1986) and Kuntz and others (2007) and are not discussed further here. Radiocarbon ages of lava flows of the Craters of the Moon lava field that extend into the Lake Walcott quadrangle are shown on the Correlation of Map Units and are discussed in the Descriptions of Map Units.

\section{${ }^{40} \mathrm{Ar} /{ }^{39} \mathrm{Ar}$ Studies of Basaltic Lava Fields in the North Half of the Lake Walcott $30^{\prime} \times 60^{\prime}$ Quadrangle}

\section{Methods}

All samples chosen for ${ }^{40} \mathrm{Ar} /{ }^{39} \mathrm{Ar}$ dating were examined petrographically to determine if they were sufficiently fresh and had minimal amounts of glass in the groundmass. Those deemed not altered and containing minimal amounts of glass were selected for dating. The samples were crushed and sieved to varying size fractions (100-200 mesh to 300-500 mesh, depending on the samples), and cleaned in an ultrasonic device in ionized water.

The ${ }^{40} \mathrm{Ar} /{ }^{39} \mathrm{Ar}$ studies were carried out in two laboratories, with differing specific dating protocols: the University of California, Santa Barbara, Calif. (UCSB), and at Rutgers University (RU), Piscataway, N.J. At UCSB, standard magnetic separation techniques and handpicking were used to amass groundmass concentrates. At RU, the entire rock was separated into at least three magnetic separates, thus every part of the sample was analyzed. Splits of each sample, ranging from 50 to 200 milligrams $(\mathrm{mg})$, were then either encapsulated in copper packets interspersed with packaged flux monitors (UCSB), or loaded into pitted aluminum disks with flux monitors (RU), and then placed into a sealed quartz vial. Vials were irradiated in cadmium-lined receptacles for 15-20 minutes at either the TRIGA reactor at the USGS in Denver or at the TRIGA reactor at Oregon State University. Samples were then analyzed either by incremental heating in a Staudacher-type resistance furnace (UCSB; Gans, 1997) or by stepwise laser heating (RU). For samples analyzed at UCSB, only groundmass concentrates of samples were analyzed, At RU, splits of three or more magnetic separates were independently run. From 6 to 15 step-heating experiments were carried out for each sample. Twelve new age determinations are given in table 1. All errors given for our estimated (preferred) ages, as reported throughout the text and in table 1 , are \pm 1 one sigma $(\sigma)$. The flux monitors used for neutron irradiations were sanidine, from either Taylor Creek Rhyolite (UCSB) with an assigned age of $27.92 \mathrm{Ma}$, or the Alder Creek Rhyolite (RU) with an assigned age of $1.196 \mathrm{Ma}$ (Dalrymple and Duffield, 1988).

At Rutgers University, active measurement of spectrometer mass discrimination is carried out throughout the unknown sample incremental data collection interval, through the use of an online automated air pipette (Turrin and others, 2010). The olivine basalt samples analyzed in this study are relatively young in age, uniformly low in potassium oxide $\left(\mathrm{K}_{2} \mathrm{O}\right)$, and have low ${ }^{40} \mathrm{Ar}_{\text {rad }}$ (radiogenic) concentrations. Such samples are particularly vulnerable to uncertainty in spectrometer mass discrimination. Realtime measurement of an air sample with zero age every 3 to 4 hours, while incrementally heating unknown samples, is the best guarantee that the significant corrections to those analyses for atmosphere argon, and for ${ }^{37} \mathrm{Ar}$ and ${ }^{36} \mathrm{Ar}$ generated by neutron irradiation, are done properly.

Virtually all of the samples collected for ${ }^{40} \mathrm{Ar} /{ }^{39} \mathrm{Ar}$ dating yielded consistent, moderately well-behaved ${ }^{40} \mathrm{Ar} /{ }^{39} \mathrm{Ar}$ data with interpretable ages and uncertainties (table 1). Most of the samples yielded fairly flat age spectra having well-defined plateaus, as described by Fleck and others (1977). These spectra are readily explainable in terms of the combined effects and variable contributions of reactor-induced recoil, low-temperature argon loss, and a non-atmospheric "trapped" component (that is, excess argon). In general, the flattest and most reliable parts of the individual spectra were associated with the gas released at lower to intermediate temperatures. Typical confidence estimates range from 6 to $50 \mathrm{ka}$.

\section{Results}

The order of laboratory-determined ages of the rocks agreed with stratigraphic order of the rocks determined independently by geologic mapping and field relations.

The new ${ }^{40} \mathrm{Ar} /{ }^{39} \mathrm{Ar}$ geochronologic data reveal an apparent bimodal age distribution of basaltic volcanism during the time span of the Brunhes Normal Polarity Chron (0 to $780 \mathrm{ka})$ (table 1). Most ages are younger than about $150 \mathrm{ka}$, with two units older than about $700 \mathrm{ka}$ (Vent 4640 [Qwfd3], and Sid 
Butte [Qwfe1]). Two ages lie between these values (Higgins Blowout lava field, Qwfc3, 289 $\pm 5 \mathrm{ka}$; and Adelaide Butte, $475 \pm 38 \mathrm{ka}$; table 1). Numerous map units of modest areal extent and of intermediate age appearance were not analyzed by either ${ }^{40} \mathrm{Ar} /{ }^{39} \mathrm{Ar}$ or potassium-argon (K-Ar) methods. These lava fields may have erupted at intermediate times between about $750 \mathrm{ka}$ and about $150 \mathrm{ka}$.

Most of the younger basalt eruptions $(<150 \mathrm{ka})$ in the north half of the Lake Walcott quadrangle have occurred along the Great Rift volcanic rift zone. However, two of the younger eruptions are not located near the Great Rift; they are located in the western third of this quadrangle. Kimama Butte (Qwfb17), a basalt shield volcano covering about $250 \mathrm{~km}^{2}$, is dated at $87 \pm 11 \mathrm{ka}$ (table 1). Shale Butte (Qwfb1), a complex of a'a and pahoehoe flows located in the northwest corner of the quadrangle, is dated at $19 \pm 2 \mathrm{ka}$ (table 1). Due to an odd direction of remanent magnetization recorded in Shale Butte lava flows, we believe that it erupted during a time interval of aberrant geomagnetic field dated near $19 \pm 2 \mathrm{ka}$ (table 1) and called the Hilina Pali Excursion (Coe and others, 1978). This age assignment is slightly older than one standard deviation of the weighted mean plateau age from the ${ }^{40} \mathrm{Ar} /{ }^{39} \mathrm{Ar}$ studies.

\section{Whole-Rock Potassium-Argon Studies and Results}

One sample of pre-Holocene lava flows in this quadrangle was dated by the K-Ar method (Sand Butte, table 1). K-Ar dating of the pre-Holocene lava flows was hampered by the low $\mathrm{K}_{2} \mathrm{O}$ contents of the flows (typically less than 0.8 percent), the relative youth of the flows, and mass spectrometric and electronic limitations. The one experiment was successful on a sample from Sand Butte (Qsbb6; 34 $\pm 29 \mathrm{ka}$, table 1). The Sand Butte vent is located just north of the northern boundary of the Lake Walcott quadrangle in the Craters of the Moon $30^{\prime} \times 60^{\prime}$ quadrangle.

\section{Paleomagnetic Studies}

\section{Methods}

Magnetic polarity and remanent inclination and declination directions (table 2) were determined for basaltic lava flows from surface samples. Paleomagnetic site-average data (table 2) are ordered by lava field location north to south, within three west-to-east corridors: (1) lava fields west of the Great Rift volcanic rift zone, (2) lava fields in the Great Rift volcanic rift zone, and (3) lava fields east of the Great Rift volcanic rift zone. Eleven site averages included in table 2 are not located within the boundaries of north half of the Lake Walcott $30^{\prime} \times 60^{\prime}$ quadrangle; they are included in the paleomagnetic data for completeness, and to emphasize that several of the lava fields on this map extend northward into the Craters of the Moon 30'×60' quadrangle (Kuntz and others, 2007).

\section{Results and Interpretations}

All lava flows except two, Sid Butte (Qwfe1) and Vent 4559 (Qwfe2) in this quadrangle, have normal polarity and were emplaced during the Brunhes Normal Polarity Chron, and are younger than 780,000 yrs. Secular variation of the geomagnetic field occurs at a geologically rapid rate (about $4^{\circ}$ per century; Champion and Shoemaker, 1977), which allows grouping of lava flows having similar paleomagnetic directions. Conversely, dissimilar paleomagnetic directions indicate that two lava flows erupted at different times. With these two ideas as guides and by incorporating the new ${ }^{40} \mathrm{Ar} /{ }^{39} \mathrm{Ar}$ and $\mathrm{K}-\mathrm{Ar}$ ages, we used directions of remanent magnetization to correlate and approximately date lava fields for this map. The paleomagnetic field studies were highly successful in identifying the full extent of two basalt shield and (or) lava-tube eruptions in the center part of the Lake Walcott quadrangle. The older eruption from vents in

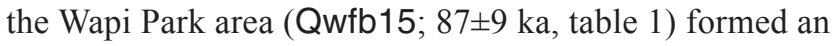
extensive lava-tube system that enabled lava to move in a broad flow field as much as $24 \mathrm{~km}$ to the west. This flow field is partly overlain by the Holocene Wapi lava field (Qwfa2; $2,270 \pm 50{ }^{14} \mathrm{C}$ yr before present [B.P.], Kuntz, Spiker, and others, 1986); therefore, its full extent cannot be determined. The younger eruption ( $73 \pm 8 \mathrm{ka}$, table 1$)$ was from aligned vents in the Inferno Chasm volcanic rift zone, including Horse Butte (Qsbb25), Cottrells Blowout (Qwfb14), and Inferno Chasm (Qwfb12). A double lava-tube system, called the Bear Trap lava-tube system (Greeley, 1982; King, 1982) facilitated the movement of lava as far as $42 \mathrm{~km}$ westward across the north-central part of the Lake Walcott quadrangle. This lava field is significantly masked by younger, mostly Holocene lava flows of the Craters of the Moon lava field, and also by the younger lava flows of the Grandview Crater lava field (Qwfb3; $38 \pm 12 \mathrm{ka}$, table 1); thus, its full extent can only be inferred.

The extents of other lava fields have been identified through paleomagnetic field studies. Split Butte (Qwfc1; $138 \pm 6 \mathrm{ka}$, table 1), a maar volcano located on the western margin of the Holocene Wapi lava field (Qwfa2; 2,270 $\pm 50{ }^{14} \mathrm{C}$ yr B.P., Kuntz, Spiker, and others, 1986) has an odd direction of remanent magnetization. A correlative area of lava flows was identified more than $11 \mathrm{~km}$ to the southwest near the southern boundary of this quadrangle.

Several aerially contiguous lava fields are correlative because they have identical or similar paleomagnetic directions. For example, the Inferno Chasm vent complex has five correlative lava fields, the Claasen vent complex has seven correlative lava fields, and the Flat Top vent complex has six correlative lava fields. 
Table 2. Paleomagnetic data for the north half of the Lake Walcott $30^{\prime} \times 60^{\prime}$ quadrangle, Idaho.

[Site label, alphanumeric identifier of location; latitude and longitude in degrees north and east in North American Datum of 1927 (NAD 27) of the site location; N/No, number of cores used compared with the number originally taken at the site; Exp., strength of the peak alternating demagnetizing field in milliTeslas (mT); NRM, means no alternating-field demagnitization was done after confirming it was unnecessary; Li, line site solution; Pl, plane solution; Mx, mixed line and plane site solution; I and D, remanent inclination and declination in degrees; $\alpha 95$, 95 percent confidence limit about the mean direction in degrees; k, estimate of the Fisherian precision parameter; R, length of the resultant vector; and P latitude, P longitude, location in degrees north and east of the virtual geomagnetic pole (VGP) calculated from the site mean direction; Averaged lat/long data for mean of the site, means is required to calculate averaged VGP position;--, no data]

\begin{tabular}{|c|c|c|c|c|c|c|c|c|c|c|c|c|c|}
\hline Site name & $\begin{array}{c}\text { Map unit } \\
\text { symbol }\end{array}$ & $\begin{array}{l}\text { Site } \\
\text { label }\end{array}$ & Latitude & Longitude & N/No & Exp. & $\mathbf{I}$ & D & $\alpha 95$ & $\mathbf{k}$ & $\mathbf{R}$ & $\begin{array}{c}\mathrm{P} \\
\text { latitude }\end{array}$ & $\begin{array}{c}\mathbf{P} \\
\text { longitude }\end{array}$ \\
\hline \multicolumn{14}{|c|}{ Vents west of the Great Rift volcanic rift zone } \\
\hline \multirow{4}{*}{ Black Ridge Crater lava field } & \multirow{4}{*}{ Qsbb14 } & $554 \mathrm{~B} 2^{1}$ & 43.025 & 246.044 & $8 / 8$ & $30+$ & 63.0 & 346.8 & 2.4 & 522 & 7.987 & 80.4 & 169.4 \\
\hline & & $551 \mathrm{~B} 4^{1}$ & 42.900 & 245.941 & $7 / 8$ & $\mathrm{Pl}$ & 59.2 & 348.7 & 3.1 & 352 & -- & 81.1 & 140.8 \\
\hline & & 226B7 & 42.982 & 246.080 & $8 / 8$ & 20 & 63.4 & 347.2 & 1.5 & 1,346 & 7.99480 & 80.6 & 172.8 \\
\hline & & & 43.0 & 246.0 & $3 / 3$ & & 61.9 & 347.6 & 3.6 & 1,172 & 2.99829 & 81.0 & 160.8 \\
\hline \multirow{3}{*}{ Sand Butte lava field } & \multirow{3}{*}{ Qsbb6 } & $610 \mathrm{~B} 2^{1}$ & 43.177 & 246.148 & $8 / 8$ & 30 & 66.0 & 7.1 & 2.0 & 768 & 7.99089 & 82.9 & 287.5 \\
\hline & & $626 \mathrm{~B} 2^{1}$ & 43.084 & 246.181 & $7 / 8$ & $30+$ & 66.2 & 358.6 & 1.5 & 1,664 & 6.99639 & 84.4 & 236.9 \\
\hline & & & 43.1 & 246.16 & $2 / 2$ & -- & 66.2 & 2.9 & 7.5 & 1,105 & 1.99910 & 84.2 & 265.4 \\
\hline \multirow{3}{*}{ West Wildhorse Butte lava field } & \multirow{3}{*}{ Qsbb8 } & $594 \mathrm{~B} 2^{1}$ & 43.071 & 246.257 & $8 / 8$ & 20 & 57.8 & 20.1 & 2.0 & 807 & 7.99133 & 74.1 & 346.5 \\
\hline & & $605 \mathrm{~B} 3$ & 42.954 & 246.251 & $7 / 8$ & $30+$ & 62.4 & 18.7 & 2.3 & 719 & 6.99166 & 76.4 & 326.6 \\
\hline & & & 43.02 & 246.25 & $2 / 2$ & -- & 60.1 & 19.5 & 10.2 & 607 & 1.99835 & 75.4 & 337.5 \\
\hline \multirow{3}{*}{ Shale Butte lava field } & \multirow{3}{*}{ Qwfb1 } & 995B4 & 42.988 & 246.195 & $8 / 8$ & 20 & 36.9 & 25.6 & 1.1 & 2,435 & 7.997 & 59.0 & 14.4 \\
\hline & & 234B7 & 42.974 & 246.144 & $3 / 3$ & 30 & 39.3 & 26.8 & 10.9 & 129 & 2.985 & 59.7 & 10.6 \\
\hline & & & 42.98 & 246.17 & $2 / 2$ & -- & 38.1 & 26.2 & 5.6 & 1,974 & 1.999 & 59.3 & 12.5 \\
\hline Vent 4371' lava field & Qwfd7 & $597 \mathrm{~B} 3$ & 42.933 & 246.293 & $7 / 8$ & Pl & 59.2 & 352.4 & 3.8 & 328 & -- & 83.6 & 131.5 \\
\hline Adelaide Butte lava field & Qwfd3 & 757B3 & 42.823 & 246.233 & $7 / 8$ & 30 & 40.0 & 0.3 & 1.9 & 997 & 6.994 & 87.4 & 275.0 \\
\hline Sid Butte lava field & Qwfe1 & $773 \mathrm{~B} 3$ & 42.875 & 246.021 & $7 / 8$ & 30 & -51.3 & 176.5 & 2.2 & 740 & 6.992 & -78.7 & 261.3 \\
\hline \multirow{2}{*}{ Vent 4373' lava field } & \multirow{2}{*}{ Qwfe3 } & 971B4 & 42.815 & 246.020 & $7 / 8$ & $30+$ & -57.6 & 175.9 & 4.7 & 164 & 6.963 & -84.4 & 281.4 \\
\hline & & & 42.85 & 246.020 & $2 / 2$ & -- & -54.5 & 176.2 & 13.8 & 330 & 1.997 & -81.6 & 267.7 \\
\hline Vent 4559 lava field & Qwfe2 & $573 \mathrm{~B} 3$ & 42.874 & 246.427 & $7 / 8$ & 50 & -65.6 & 167.8 & 3.3 & 336 & 6.982 & -80.1 & 10.5 \\
\hline Vent 4401' lava field & Qwfd5 & $557 \mathrm{~B} 3$ & 42.837 & 246.436 & $8 / 8$ & 20 & 56.7 & 19.6 & 2.1 & 724 & 7.990 & 74.0 & 350.2 \\
\hline Vent 4429' lava field & Qwfd6 & 549B3 & 42.822 & 246.435 & $7 / 8$ & $\mathrm{Pl}$ & 51.3 & 348.6 & 7.9 & 84 & -- & 75.9 & 109.9 \\
\hline
\end{tabular}


Table 2. Paleomagnetic data for the north half of the Lake Walcott $30^{\prime} \times 60^{\prime}$ quadrangle, Idaho.-Continued

[Site label, alphanumeric identifier of location; latitude and longitude in degrees north and east in North American Datum of 1927 (NAD 27) of the site location; N/No, number of cores used compared with the number originally taken at the site; Exp., strength of the peak alternating demagnetizing field in milliTeslas (mT); NRM, means no alternating-field demagnitization was done after confirming it was unnecessary; Li, line site solution; Pl, plane solution; Mx, mixed line and plane site solution; I and D, remanent inclination and declination in degrees; $\alpha 95,95$ percent confidence limit about the mean direction in degrees; k, estimate of the Fisherian precision parameter; R, length of the resultant vector; and P latitude, P longitude, location in degrees north and east of the virtual geomagnetic pole (VGP) calculated from the site mean direction; Averaged lat/long data for mean of the site, means is required to calculate averaged VGP position;--, no data]

\begin{tabular}{|c|c|c|c|c|c|c|c|c|c|c|c|c|c|}
\hline Site name & $\begin{array}{c}\text { Map unit } \\
\text { symbol }\end{array}$ & $\begin{array}{l}\text { Site } \\
\text { label }\end{array}$ & Latitude & Longitude & N/No & Exp. & $\mathbf{I}$ & D & $\alpha 95$ & k & $\mathbf{R}$ & $\begin{array}{c}\mathbf{P} \\
\text { latitude }\end{array}$ & $\begin{array}{c}\text { P } \\
\text { longitude }\end{array}$ \\
\hline The Crater lava field & Qwfd4 & 979B4 & 42.791 & 246.197 & $8 / 8$ & $\mathrm{Pl}$ & 51.6 & 9.5 & 2.0 & 728 & -- & 77.1 & 27.6 \\
\hline Kimama Butte lava field & Qwfb17 & 765B3 & 42.84 & 246.202 & $8 / 8$ & 30 & 40.0 & 0.3 & 1.3 & 1,858 & 7.996 & 69.9 & 65.3 \\
\hline Knoll Vent lava field & Qwfd9 & $527 \mathrm{~B} 41$ & 42.73 & 246.010 & $8 / 8$ & Pl & 63.0 & 355.0 & 2.6 & 535 & -- & 86.0 & 183.3 \\
\hline \multirow{3}{*}{ Vent 4354' lava field } & \multirow{3}{*}{ Qwfc13 } & $670 \mathrm{~B} 41$ & 42.744 & 246.559 & $9 / 9$ & 30 & 58.1 & 18.6 & 3.5 & 219 & 8.963 & 75.4 & 346.2 \\
\hline & & 978B4 & 42.778 & 246.945 & $7 / 8$ & 30 & 56.8 & 15.6 & 2.1 & 868 & 6.993 & 77.0 & 355.6 \\
\hline & & & 42.76 & 246.53 & $2 / 2$ & -- & 57.5 & 17.1 & 4.5 & 3,057 & 2.000 & 76.2 & 350.6 \\
\hline \multicolumn{14}{|c|}{ Vents in and adjacent to the Great Rift volcanic rift zone } \\
\hline \multirow{8}{*}{ Horse Butte lava field } & \multirow{8}{*}{ Qsbb25 } & $530 \mathrm{~B} 2^{1}$ & 43.028 & 246.769 & $8 / 8$ & $40+$ & 48.9 & 4.7 & 1.5 & 1,296 & 7.995 & 76.2 & 49.5 \\
\hline & & $501 \mathrm{~B} 3^{1}$ & 43.082 & 246.762 & $8 / 8$ & 20 & 51.5 & 2.0 & 1.0 & 2,906 & 7.998 & 79.0 & 58.1 \\
\hline & & $589 \mathrm{~B} 3$ & 42.951 & 246.364 & $8 / 8$ & 20 & 48.7 & 2.2 & 1.9 & 841 & 7.992 & 76.6 & 58.1 \\
\hline & & $581 \mathrm{~B} 3$ & 42.948 & 246.467 & $8 / 8$ & 30 & 47.5 & 0.5 & 2.4 & 551 & 7.987 & 75.7 & 64.8 \\
\hline & & 939B4 & 42.908 & 246.508 & $8 / 8$ & 20 & 48.5 & 1.8 & 1.0 & 3,205 & 7.998 & 76.5 & 59.9 \\
\hline & & $525 \mathrm{~B} 3$ & 42.966 & 246.657 & $8 / 8$ & 20 & 47.1 & 3.2 & 1.2 & 2,124 & 7.997 & 75.1 & 55.8 \\
\hline & & 533B3 & 42.993 & 246.671 & $8 / 8$ & 30 & 48.2 & 0.7 & 1.2 & 2,187 & 7.997 & 76.2 & 64.1 \\
\hline & & $947 \mathrm{~B} 4^{1}$ & 43.008 & 246.367 & $8 / 8$ & 20 & 49.3 & 3.2 & 1.1 & 2,366 & 7.997 & 79.6 & 54.1 \\
\hline Vent 5094' \& Vent 5108' lava fields & Qsbb24 & 741B3 & 42.961 & 246.793 & $8 / 8$ & 30 & 44.2 & 3.9 & 1.7 & 1,070 & 7.993 & 72.7 & 55.1 \\
\hline Cottrells Blowout lava field & Qwfb14 & 733B3 & 42.990 & 246.817 & $8 / 8$ & 30 & 47.1 & 1.4 & 2.2 & 630 & 7.989 & 75.2 & 61.9 \\
\hline \multirow{2}{*}{ Inferno Chasm lava field } & \multirow{2}{*}{ Qwfb12 } & $725 \mathrm{~B} 3$ & 42.959 & 246.800 & $7 / 8$ & $\mathrm{Pl}$ & 46.4 & 1.6 & 2.6 & 460 & -- & 74.7 & 61.4 \\
\hline & & 717B3 & 42.964 & 246.749 & $6 / 8$ & $30+$ & 48.7 & 0.6 & 4.1 & 263 & 5.981 & 76.7 & 64.4 \\
\hline \multirow{2}{*}{ East Inferno Chasm lava field } & \multirow{2}{*}{ Qwfb13 } & 661B3 & 42.964 & 246.876 & $8 / 8$ & $30+$ & 49.7 & 1.7 & 1.6 & 1,153 & 7.994 & 77.5 & 60.2 \\
\hline & & & 42.97 & 246.6 & $13 / 13$ & -- & 48.2 & 2.2 & 1.0 & 1,694 & 12.993 & 76.1 & 58.6 \\
\hline
\end{tabular}


Table 2. Paleomagnetic data for the north half of the Lake Walcott $30^{\prime} \times 60^{\prime}$ quadrangle, Idaho.-Continued

[Site label, alphanumeric identifier of location; latitude and longitude in degrees north and east in North American Datum of 1927 (NAD 27) of the site location; N/No, number of cores used compared with the number originally taken at the site; Exp., strength of the peak alternating demagnetizing field in milliTeslas (mT); NRM, means no alternating-field demagnitization was done after confirming it was unnecessary; Li, line site solution; Pl, plane solution; Mx, mixed line and plane site solution; I and D, remanent inclination and declination in degrees; $\alpha 95$, 95 percent confidence limit about the mean direction in degrees; k, estimate of the Fisherian precision parameter; R, length of the resultant vector; and P latitude, P longitude, location in degrees north and east of the virtual geomagnetic pole (VGP) calculated from the site mean direction; Averaged lat/long data for mean of the site, means is required to calculate averaged VGP position;--, no data]

\begin{tabular}{|c|c|c|c|c|c|c|c|c|c|c|c|c|c|}
\hline Site name & $\begin{array}{l}\text { Map unit } \\
\text { symbol }\end{array}$ & $\begin{array}{c}\text { Site } \\
\text { label }\end{array}$ & Latitude & Longitude & N/No & Exp. & I & D & $\alpha 95$ & k & $\mathbf{R}$ & $\begin{array}{c}\mathbf{P} \\
\text { latitude }\end{array}$ & $\begin{array}{c}\text { P } \\
\text { longitude }\end{array}$ \\
\hline \multirow{3}{*}{ Grandview Crater lava field } & \multirow{3}{*}{ Qwfb3 } & 693B3 & 42.909 & 246.870 & $8 / 8$ & 30 & 77.8 & 340.2 & 3.2 & 310 & 6.977 & 64.0 & 229.0 \\
\hline & & 701B3 & 42.928 & 246.820 & $8 / 8$ & 20 & 72.7 & 335.9 & 4.6 & 148 & 7.953 & 68.7 & 210.3 \\
\hline & & & 42.92 & 246.85 & $2 / 2$ & -- & 75.3 & 337.7 & 11.4 & 483 & 1.998 & 66.7 & 220.4 \\
\hline \multirow{8}{*}{ Wapi Park lava field } & \multirow{8}{*}{ Qwfb15 } & 509B3 & 42.913 & 246.614 & $6 / 8$ & 30 & 54.2 & 351.6 & 2.2 & 963 & 5.995 & 79.5 & 108.3 \\
\hline & & 517B3 & 42.884 & 246.635 & $8 / 8$ & 30 & 55.1 & 351.7 & 1.7 & 1,118 & 7.994 & 80.3 & 111.0 \\
\hline & & $565 \mathrm{~B} 3$ & 42.849 & 246.448 & $8 / 8$ & 40 & 53.3 & 349.7 & 1.8 & 1,006 & 7.993 & 77.9 & 111.9 \\
\hline & & 709B3 & 42.919 & 246.793 & $8 / 8$ & 30 & 56.0 & 350.4 & 1.0 & 2,933 & 7.998 & 80.2 & 119.3 \\
\hline & & 695B4 & 42.804 & 246.659 & $8 / 8$ & 30 & 52.7 & 354.4 & 1.6 & 1,229 & 7.994 & 79.5 & 93.2 \\
\hline & & 703B4 & 42.845 & 246.645 & $8 / 8$ & $30+$ & 54.6 & 354.2 & 1.4 & 1,518 & 7.996 & 81.1 & 98.9 \\
\hline & & 931B4 & 42.898 & 246.508 & $8 / 8$ & 30 & 54.8 & 353.4 & 1.1 & 2,802 & 7.998 & 80.9 & 102.9 \\
\hline & & & 42.9 & 246.6 & $7 / 7$ & -- & 54.4 & 352.2 & 1.2 & 2,743 & 6.998 & 80.0 & 106.4 \\
\hline \multirow{3}{*}{ Split Butte lava field } & \multirow{3}{*}{ Qwfc1 } & 921B4 & 42.897 & 246.626 & $10 / 10$ & $\mathrm{Pl}$ & 26.2 & 334.9 & 2.5 & 461 & -- & 53.8 & 110.8 \\
\hline & & 711B4 & 42.782 & 246.549 & $6 / 8$ & $\mathrm{Pl}$ & 28.1 & 336.8 & 7.8 & 90 & -- & 55.8 & 109.2 \\
\hline & & & 42.8 & 246.6 & $2 / 2$ & -- & 27.2 & 335.8 & 5.6 & 2,031 & 2.000 & 54.8 & 110.1 \\
\hline \multirow{2}{*}{ Wapi lava field } & \multirow{2}{*}{ Qwfa2 } & WapI $1 / 2$ & 42.804 & 246.881 & $13 / 13$ & NRM & 62.8 & 12.5 & 1.2 & 1,142 & 12.989 & 80.8 & 323.9 \\
\hline & & WapI $3 / 4$ & 42.9 & 246.767 & $12 / 12$ & NRM & 62.8 & 13.9 & 1.5 & 827 & 11.987 & 79.9 & 325.0 \\
\hline \multirow{2}{*}{ Kings Bowl lava field } & \multirow{2}{*}{ Qwfa1 } & KBII & 42.949 & 246.785 & $24 / 24$ & NRM & 61.9 & 13.2 & 1.0 & 906 & 23.975 & 80.4 & 331.2 \\
\hline & & & 42.9 & 246.8 & $3 / 3$ & -- & 62.5 & 13.2 & 0.9 & 18,936 & 3.000 & 80.4 & 326.7 \\
\hline \multirow{4}{*}{ Higgins Blowout } & \multirow{4}{*}{ Qwfc3 } & $541 \mathrm{~B} 3$ & 42.768 & 246.622 & $6 / 8$ & 30 & 57.5 & 331.20 & 1.4 & 2,190 & 5.998 & 67.7 & 154.3 \\
\hline & & 679B4 & 42.775 & 246.707 & $8 / 8$ & $\mathrm{Pl}$ & 57.2 & 328.00 & 3.1 & 269 & -- & 65.3 & 156.0 \\
\hline & & 687B4 & 42.775 & 246.686 & $8 / 8$ & 30 & 58.5 & 323.90 & 1.7 & 1,132 & 7.994 & 62.7 & 161.6 \\
\hline & & & 42.77 & 246.66 & $3 / 3$ & -- & 57.8 & 327.70 & 3.1 & 1,547 & 2.999 & 65.3 & 157.5 \\
\hline \multicolumn{14}{|c|}{ Vents east of the Great Rift volcanic rift zone } \\
\hline \multirow{2}{*}{ Vent 5270 ' lava field } & \multirow{2}{*}{ Qsbc60 } & $645 \mathrm{~B} 3$ & 42.983 & 246.896 & $8 / 8$ & $40+$ & 61.7 & 335.4 & 1.9 & 835 & 7.992 & 72.1 & 165.0 \\
\hline & & & 43.0 & 246.9 & $3 / 3$ & -- & 63.7 & 336.3 & 2.9 & 1,790 & 2.999 & 72.9 & 172.9 \\
\hline
\end{tabular}


Table 2. Paleomagnetic data for the north half of the Lake Walcott $30^{\prime} \times 60^{\prime}$ quadrangle, Idaho.-Continued

[Site label, alphanumeric identifier of location; latitude and longitude in degrees north and east in North American Datum of 1927 (NAD 27) of the site location; N/No, number of cores used compared with the number originally taken at the site; Exp., strength of the peak alternating demagnetizing field in milliTeslas (mT); NRM, means no alternating-field demagnitization was done after confirming it was unnecessary; Li, line site solution; Pl, plane solution; Mx, mixed line and plane site solution; I and D, remanent inclination and declination in degrees; $\alpha 95,95$ percent confidence limit about the mean direction in degrees; k, estimate of the Fisherian precision parameter; R, length of the resultant vector; and P latitude, P longitude, location in degrees north and east of the virtual geomagnetic pole (VGP) calculated from the site mean direction; Averaged lat/long data for mean of the site, means is required to calculate averaged VGP position;--, no data]

\begin{tabular}{|c|c|c|c|c|c|c|c|c|c|c|c|c|c|}
\hline Site name & $\begin{array}{l}\text { Map unit } \\
\text { symbol }\end{array}$ & $\begin{array}{c}\text { Site } \\
\text { label }\end{array}$ & Latitude & Longitude & N/No & Exp. & I & D & $\alpha 95$ & k & $\mathbf{R}$ & $\begin{array}{c}\mathbf{P} \\
\text { latitude }\end{array}$ & $\begin{array}{c}\text { P } \\
\text { longitude }\end{array}$ \\
\hline \multirow{2}{*}{ Flat Top lava field } & \multirow{2}{*}{ Qwfc4 } & $621 \mathrm{~B} 3$ & 42.995 & 246.934 & $7 / 8$ & 30 & 73.6 & 19.8 & 2.1 & 838 & 6.993 & 69.5 & 276.3 \\
\hline & & $629 \mathrm{~B} 3$ & 42.982 & 246.935 & $7 / 8$ & 50 & 75.7 & 17.0 & 1.9 & 986 & 6.994 & 67.7 & 267.3 \\
\hline Streifling lava field & Qsbc59 & 613B3 & 42.995 & 246.959 & $8 / 8$ & 30 & 74.0 & 37.1 & 2.0 & 754 & 7.991 & 61.9 & 286.4 \\
\hline \multirow{2}{*}{ Vent 5026' lava field } & \multirow{2}{*}{ Qwfc5 } & 637B3 & 42.972 & 246.934 & $8 / 8$ & $\mathrm{Pl}$ & 72.3 & 22.2 & 4.6 & 140 & -- & 69.9 & 283.2 \\
\hline & & 662B4 & 42.950 & 246.924 & $8 / 8$ & $\mathrm{Pl}$ & 75.9 & 7.5 & 3.5 & 282 & -- & 69.2 & 256.4 \\
\hline \multirow{2}{*}{ Vent 4822' lava field } & \multirow{2}{*}{ Qwfc6 } & $669 \mathrm{~B} 3$ & 42.921 & 246.949 & $7 / 8$ & $40+$ & 77.2 & 18.9 & 2.2 & 772 & 6.992 & 65.1 & 265.5 \\
\hline & & & 42.98 & 246.94 & $6 / 6$ & -- & 75.0 & 20.8 & 2.6 & 689 & 5.993 & 67.6 & 273.1 \\
\hline Vent 5329 lava field & Qsbb34 & 653B3 & 42.968 & 246.837 & $8 / 8$ & 30 & 62.1 & 345.6 & 1.1 & 2,421 & 7.997 & 79.5 & 163.8 \\
\hline Claasen lava field & Qwfb4 & 4380B & 42.849 & 246.914 & $8 / 8$ & $\mathrm{Li}$ & 59.7 & 34.2 & 2.5 & 504 & 7.986 & 64.5 & 330.3 \\
\hline Vent 4829' lava field & Qwfb6 & 4300B & 42.849 & 246.930 & $8 / 8$ & $\mathrm{Mx}$ & 64.7 & 30.5 & 1.5 & 1,385 & 7.995 & 68.2 & 316.5 \\
\hline Vent 4801' lava field & Qwfb7 & 677B3 & 42.839 & 246.899 & $8 / 8$ & 30 & 56.8 & 32.8 & 2.5 & 487 & 7.986 & 64.5 & 338.1 \\
\hline Vent $4862^{\prime}$ lava field & Qwfb8 & 4460B & 42.860 & 246.914 & $8 / 8$ & $\mathrm{Mx}$ & 59.3 & 27.4 & 2.5 & 567 & 7.988 & 69.4 & 335.3 \\
\hline \multirow{2}{*}{ Winters Blowout Lava field } & \multirow{2}{*}{ Qwfb5 } & 685B3 & 42.895 & 246.895 & $7 / 8$ & 30 & 59.5 & 26.9 & 2.6 & 539 & 6.989 & 69.8 & 335.1 \\
\hline & & & 42.86 & 246.91 & $5 / 5$ & -- & 60.0 & 30.4 & 3.1 & 600 & 4.993 & 67.4 & 331.4 \\
\hline Vent 4640 ' lava field & Qwfd1 & 4540B & 42.806 & 246.942 & $7 / 8$ & $\mathrm{Mx}$ & 69.4 & 349.9 & 2.0 & 1,183 & 6.995 & 77.7 & 217.3 \\
\hline \multirow{2}{*}{ "Bower" vent E of vent 4640 ' } & \multirow{2}{*}{ Qwfd1 } & $4620 \mathrm{~B}^{1}$ & 42.835 & 247.032 & $7 / 8$ & $\mathrm{Li}$ & 71.2 & 345.2 & 1.3 & 2,036 & 6.997 & 74.0 & 215.7 \\
\hline & & & 42.82 & 246.99 & $2 / 2$ & -- & 70.3 & 347.7 & 5.2 & 2,286 & 2.000 & 75.9 & 216.4 \\
\hline Vent 4645 ' lava field & Qwfb19 & 749B3 & 42.762 & 246.843 & $8 / 8$ & $\mathrm{Pl}$ & 62.6 & 331.6 & 1.3 & 1,739 & -- & 69.4 & 170. \\
\hline
\end{tabular}

${ }^{1}$ Indicates site is not located within the boundary of the north half of the Lake Walcott $30^{\prime} \times 60^{\prime}$ quadrangle. 


\section{DESCRIPTION OF MAP UNITS}

[Description of rock types in the Description of Map Units follows common terms used in field descriptions of basaltic volcanic rocks. Minerals in lava flows and mineral dimensions were identified by typical hand-specimen investigation using a hand lens and millimeter $(\mathrm{mm})$ scale. Rock colors were assigned by field inspection. The description of mineralogy and textures of rocks are given for samples collected locally; the descriptions may not reflect crystal sizes, proportions, or textures that may be obtained for a sample of the same lava field collected elsewhere. Where measured, normal magnetic polarity indicates age younger than $780 \mathrm{ka}$ and reversed magnetic polarity indicates age older than $780 \mathrm{ka}$ ]

\section{UNCONSOLIDATED SURFICIAL DEPOSITS}

Qes Eolian sand (Holocene to early middle Pleistocene) —Fine to medium sand, well sorted. Typically forms barchan and longitudinal dunes. Much of source material derived from alluvial sediment deposited along Snake River southwest of map area in the vicinity of Lake Walcott, chiefly during the Bonneville Flood about 14,500 yr ago (Malde, 1968; O'Connor, 1993). Thickness $0-15 \mathrm{~m}$

Qp Playa deposits (Holocene to early middle Pleistocene) - Silty sand to clayey silt; minor gravel and scattered boulders of basalt along margins. Fills depressions along contacts between lava flows. Deposited along low-gradient ephemeral streams and in ephemeral lakes. Thickness $0-10 \mathrm{~m}$

\section{HOLOCENE AND PLEISTOCENE BASALTIC LAVA FLOWS AND RELATED NEAR-VENT PYROCLASTIC AND ERUPTIVE-FISSURE DEPOSITS OF THE SNAKE RIVER GROUP}

\section{ERUPTIVE PERIOD A}

Qwfa1

Surface- and fountain-fed, proximal, medial, and distal basaltic pahoehoe lava flows of the Kings Bowl lava field (Holocene)-The Kings Bowl lava field is characterized by thin, fissure-fed flows adjacent to the 7-km-long set of eruptive fissures of the Great Rift volcanic rift zone. The eruptive fissures consist of linear, discontinuous, en echelon cracks that are $2-3 \mathrm{~m}$ wide and locally filled with feeder dikes and breccia. The eruptive fissures are flanked by parallel, non-eruptive fissures that are 600 meters $(\mathrm{m})$ to as much as 1.1 kilometers $(\mathrm{km})$ from the main fissure. Thin, fissure-fed, shelly-pahoehoe flows, lava ponds, low lake levees, spatter ramparts, small spatter cones, and a large explosion pit characterize the lava field adjacent to the eruptive fissures. Spatter ramparts and spatter cones are prominent in the vicinity of Creons Cave and South Grotto. Kings Bowl is an 85-m-long, $30 \mathrm{~m}$-wide, and 30-m-deep explosion pit. A lava pond surrounded the site of Kings Bowl prior to the explosion. Prominent basalt mounds, believed to be the remnants of levees, define the limits of the lava pond. Blocks as large as $10 \mathrm{~m}$ in diameter were hurled westward from Kings Bowl for distances of up to $245 \mathrm{~m}$; many of the large blocks broke through the crust of the lava pond. A lightcolored blanket of tephra spread eastward from the explosion pit; tephra about $1 \mathrm{~mm}$ in diameter occurs as far east as $1.2 \mathrm{~km}$ from Kings Bowl. The tephra blanket has an area of $0.15 \mathrm{~km}^{2}$. Calculations by King (1977) show that the volume of ejected tephra falls far short of that needed to fill the cavity at Kings Bowl. This indicates collapse of the vent area subsequent to the explosive event, or shattering of the material originally in the cavity to dimensions much smaller than $1 \mathrm{~mm}$ and dispersal of the finegrained material far beyond the vicinity of Kings Bowl. Crystal Ice Cave is a locality on the eruptive fissure north of Kings Bowl in which ice stalagmites and stalactites occur. The path to the ice features has been closed by the NPS and BLM because they cannot maintain the trail to the ice features. In addition, if access to the ice features were to remain open, the ice would melt away due to ingress of relatively hot surface air. The Kings Bowl field is small, consisting of about 0.005 cubic kilometers $\left(\mathrm{km}^{3}\right)$ of pahoehoe lava flows that cover an area of about $3.3 \mathrm{~km}^{2}$. Kuntz and others (1992) 
surmised that the Kings Bowl lava field formed within a matter of a few hours or a few days. A radiocarbon age of 2,130 $\pm 130{ }^{14} \mathrm{C}$ yr before the present (B.P.) has been determined for the lava field (Prinz, 1970). The precise location of the sample is unknown, so it is not plotted on the map.

Qwfa2

Proximal, medial, and distal, chiefly tube-fed, basaltic pahoehoe lava flows and near-vent deposits of the Wapi lava field (Holocene) - The Wapi lava field is a monogenetic, shield-type lava field that covers about $325 \mathrm{~km}^{2}$ and has a volume of about $5 \mathrm{~km}^{3}$ of lava flows. Paleomagnetic studies by Champion and Shoemaker (1977) show that all areas of the lava field have the same paleomagnetic direction, suggesting that the entire lava field formed within a few months, years, or decades. The nearly identical paleomagnetic directions of the Wapi and Kings Bowl lava fields suggest that they are part of the same eruptive event. The slopes of the lava field are typically less than 1 degree, a consequence of very fluid pahoehoe lava flows and high rates of lava effusion. Steeper slopes occur at Pillar Butte, the summit region of the lava field, where slopes are as high as $7^{\circ}$. Pillar Butte is a mass of agglutinated, shelly pahoehoe flows, possibly injected by dikes. The vent region consists of 11 eruptive centers indented by pit craters; there is abundant evidence of former lava ponds. Near-vent flows are typically a few hundred meters long, contain many small lava tubes and channels that distributed surface-fed flows. Many flows in the vent area are pahoehoe near the vent but transition into slab pahoehoe flows near their termini. Dashed contact enclose area of slab pahoehoe and a'a flows that surrounds vent area. Medial and distal pahoehoe flows are typified by flow ridges and collapse depressions, whereas proximal flows are leveed-channel a'a and slab pahoehoe flows and pahoehoe flows that consist largely of surface-fed pahoehoe toes. The age of the Wapi lava field is $2,270 \pm 50{ }^{14} \mathrm{C}$ yr B.P. (Kuntz, Spiker, and others, 1986)

\section{ERUPTIVE PERIOD B}

Qcfb4 Distal pahoehoe basalt lava flows of the Minidoka lava field (Holocene) - Tube- and surface-fed pahoehoe basalt flows having hummocky, billowy surfaces. Lava-tube systems carried lava as far as $35 \mathrm{~km}$ southwest from obscure source vents in the Great Rift volcanic rift zone near New Butte in the Craters of the Moon quadrangle (Kuntz and others, 2007). Distal parts of the flow are present along the northern part of this quadrangle about 12 to $25 \mathrm{~km}$ west of the Kings Bowl lava field (Qwfa1). Radiocarbon age of unit is 3,590土70 ${ }^{14} \mathrm{C}$ yr B.P. (Kuntz, Spiker, and others, 1986)

Qcfb5 Distal pahoehoe basalt lava flows of the Larkspur Park lava field (Holocene) - Surfaceand tube (?)-fed pahoehoe flows having a hummocky, billowy surface. Field relations, petrographic similarities, and paleomagnetic data indicate that the unit may be an early phase of the Minidoka lava field (Qcfb4). Distal parts of lava field cross the northern boundary of this quadrangle about $32 \mathrm{~km}$ west of the Kings Bowl lava field (Qwfa1)

\section{ERUPTIVE PERIOD E}

Qcfe2 Distal pahoehoe and a'a basalt lava flows of the Laidlaw Lake lava field (Holocene) Chiefly surface and tube (?)-fed pahoehoe basalt flows possibly from source vents at Grassy Cone in the Craters of the Moon quadrangle (Kuntz and others, 2007). Pahoehoe is hummocky and has pressure plateaus, collapse depressions, and flow ridges. Distal parts of lava field cross the northern boundary of this quadrangle about $40 \mathrm{~km}$ west of the Kings Bowl lava field (Qwfa1). Radiocarbon age of unit is $7,470 \pm 80{ }^{14} \mathrm{C} \mathrm{yr}$ B.P. (Kuntz, Spiker, and others, 1986)

\section{ERUPTIVE PERIOD H}

Qcfh1 Distal pahoehoe basalt lava flows of the Kimama lava field (late Pleistocene)-Surfaceand tube-fed hummocky, pahoehoe basalt flow. Only distal part of flow is exposed, source vent is unknown. Flow is covered by thin, discontinuous mantle of loess and 
eolian sand. Distal parts of lava field cross the northern boundary of this quadrangle about $35 \mathrm{~km}$ west of the Kings Bowl lava field (Qwfa1). Radiocarbon age of flow is $15,100 \pm 160{ }^{14} \mathrm{C}$ yr B.P. (Kuntz, Spiker, and others, 1986)

\section{ERUPTIVE PERIOD B}

Qwfb1 Near-vent pyroclastic deposits and proximal, medial, and distal pahoehoe and a'a basaltic lava flows of the Shale Butte lava field (late Pleistocene) - Chiefly older, surface-fed pahoehoe flows and younger, surface-fed a'a flows. Vent area is about $30 \mathrm{~m}$ long, and consists of three nested depressions in a small lava pond. The vent depression is surrounded by shelly pahoehoe levees. Dashed contact within unit separates older pahoehoe flows in the distal parts of the lava field from younger a'a flows in the medial and proximal parts of the lava field. A'a flows contain many lobes having steep fronts, flow ridges that are both perpendicular and convex toward the direction of flow movement, and also longitudinal furrows and cracks that are roughly parallel to flow movement. Shale Butte is the only known source vent in the Snake River Plain that erupted both pahoehoe and a'a flows. A'a is gray, dense, and all crystals are less than $1 \mathrm{~mm}$ long; pahoehoe is dark gray, coarse grained; plagioclase crystals are $\leq 10 \mathrm{~mm}$, olivine crystals are $\leq 2 \mathrm{~mm}$, and glomerophyric clots of plagioclase+olivine as large as $15 \mathrm{~mm}$ are common. Distal pahoehoe flows on the western side of lava field are mantled by thin, discontinuous loess and eolian sand. Sample for dating contained essentially no radiogenic argon, thus total fusion and isochron ages have high uncertainties. Age assigned (19 $\pm 2 \mathrm{ka}$, table 1) is based on paleomagnetic evidence that the Shale Butte eruption occurred during a time interval of aberrant geomagnetic field dated about $19 \pm 2 \mathrm{ka}$ and called the Hilina Pali Excursion (Coe and others, 1978)

Qwfb2

Near-vent, basaltic pahoehoe lava flows of the Vent 4319 lava field (late Pleistocene) Small vent aligned with vent at Shale Butte, about $4 \mathrm{~km}$ north-northwest. The rock is gray, medium grained, and contains phenocrysts of plagioclase $<8 \mathrm{~mm}$, olivine crystals $\leq 1.5 \mathrm{~mm}$, and glomerophyric clots of olivine+plagioclase crystals that are as large as $12 \mathrm{~mm}$. Vent 4319 flows believed to have been erupted early in the Vent 4319-Shale Butte eruption sequence and later surrounded by pahoehoe flows from the vent at Shale Butte (Qwfb1)

Qwfb3 Pahoehoe basaltic lava flows of the Grandview Crater lava field (late Pleistocene)Vent area is a north-northwest-elongated lava dome, about $20 \mathrm{~m}$ high, having a shallow circular vent depression about $100 \mathrm{~m}$ wide and $\leq 5 \mathrm{~m}$ deep. Flow surfaces are hummocky, containing many pressure ridges and tumuli; local relief as much as $5 \mathrm{~m}$. Rock is porphyritic, containing phenocrysts of plagioclase as long as $3 \mathrm{~mm}$ and olivine as much as $4 \mathrm{~mm}$ in diameter set in a matrix of the same minerals plus clinopyroxene and glass that are all $\leq 1 \mathrm{~mm}$. Rock also contains glomerophyric clots of olivine and olivine+plagioclase that are as much as $5 \mathrm{~mm}$ in longest dimension. ${ }^{40} \mathrm{Ar} /{ }^{39} \mathrm{Ar}$ age is $38 \pm 12 \mathrm{ka}$ (table 1)

Qsbb5 Distal basaltic pahoehoe flows of Broken Top lava field (late Pleistocene)—Surface-, channel-, and tube-fed, dark gray to medium-gray pahoehoe basalt flows. Flows erupted from a north-south trending, 830-m-long, 47-m deep slot-shaped vent at Broken Top Butte in the Craters of the Moon quadrangle, about $17 \mathrm{~km}$ north of the northern boundary of this map. Distal flow areas in this map are characterized by rough surfaces; lava mounds, tumuli cut by cracks, and tilted plates of lava. Rock is porphyritic, containing moderately elongated to elongated laths of plagioclase as long as $3 \mathrm{~mm}$, and subhedral, rounded, mostly equant olivine crystals that are $\leq 1.0 \mathrm{~mm}$. Cumulophyric clots of plagioclase+plagioclase and plagioclase+olivine are common, as is waist texture. Phenocrysts are set in a fine, intergranular matrix of plagioclase crystals, equant olivine crystals, intergranular clots of clinopyroxene intergrown with needle-like ilmenite crystals, intersertal yellow glass, and ubiquitous small crystals of opaque minerals. Flows covered by little or no loess or eolian sand. ${ }^{40} \mathrm{Ar} /{ }^{39} \mathrm{Ar}$ age is $<50 \mathrm{ka}$ (Kuntz and others, 2007) 
Qsbb6 Distal pahoehoe basaltic lava flows of the Sand Butte lava field (late Pleistocene) Distal, tube-fed, hummocky pahoehoe flows of the Sand Butte lava field are present in the northwestern part of this quadrangle north of Shale Butte. Flows contain many tumuli and broken slabs of pahoehoe, local relief is $\leq 5 \mathrm{~m}$. Rock is dark gray, weakly porphyritic and contains crystals of plagioclase and olivine typically $\leq 2 \mathrm{~mm}$ in a matrix of plagioclase, olivine, clinopyroxene, and glass $\leq 0.5 \mathrm{~mm}$. The source vent, Sand Butte, is located about $15 \mathrm{~km}$ north of the northern border of this quadrangle (Kuntz and others, 2007). Sand Butte is a tuff cone formed by the phreatomagmatic interaction of groundwater and basaltic magma (Womer and others, 1982). Geographic alignment with Broken Top Butte and similarity in paleomagnetic directions with Spud Butte suggest contemporaneity. K-Ar age is $34 \pm 29 \mathrm{ka}$ (table 1)

Qsbb8 Basaltic pahoehoe lava flows and near-vent pyroclastic deposits of West Wildhorse Butte lava field (late Pleistocene) —-Distal flows of the West Wildhorse Butte lava field occur in the northwest part of this quadrangle east of Shale Butte. Flows are characterized by many tumuli and pressure plateaus. Rock is coarse grained, containing plagioclase phenocrysts as long as $4 \mathrm{~mm}$ and olivine phenocrysts as long as $2 \mathrm{~mm}$. Glomerophyric clots of olivine, plagioclase, and plagioclase+olivine are as large as $3.5 \mathrm{~mm}$ diameter. Syntaxial bundles of as many as 10 plagioclase crystals are common. ${ }^{40} \mathrm{Ar} /{ }^{39} \mathrm{Ar}$ age is $<50 \mathrm{ka}$ (Kuntz and others, 2007)

\section{CLAASEN VENT COMPLEX (LATE PLEISTOCENE)}

The Claasen vent complex contains seven individual lava fields. Flows from five of these vents have the same paleomagnetic direction, indicating eruptions occurred within a short period of time, perhaps spanning only a few hundred years. Age relationships of overlapping flows are ambiguous; thus, a definitive sequence of eruptions in the vent complex is difficult to determine. ${ }^{40} \mathrm{Ar} /{ }^{39} \mathrm{Ar}$ age of Vent 4801 lava field (Qwfb7) in the Claasen vent complex is $68 \pm 8 \mathrm{ka}$ (table 1). Because of nearly identical paleomagnetic directions for all lava fields in the Claasen vent complex, this age applies to all of them

Qwfb4 Basaltic, near-vent, pyroclastic deposits and proximal and medial pahoehoe lava flows of Claasen lava field-Vent area for Claasen lava field consists of a north-south elongated, shallow depression about $400 \mathrm{~m}$ long. Proximal flows are pahoehoe; pyroclastic deposits are absent. A rootless vent about $600 \mathrm{~m}$ south of main vent depression consists of reddish, oxidized cinders. Medial and distal flows are farmed; loess and eolian sand cover is typically $\leq 2 \mathrm{~m}$, but greater than plow depth. Rock has a fine-grained matrix in which all crystals are $\leq 1 \mathrm{~mm}$; larger crystals of plagioclase $\leq 2 \mathrm{~mm}$ and olivine $\leq 1 \mathrm{~mm}$ are present, along with glomerophyric clots of olivine+plagioclase as large as $6 \mathrm{~mm}$

Qwfb5 Basaltic pahoehoe lava flows of the Winters Blowout lava field-Vent area consists of a circular depression about $600 \mathrm{~m}$ diameter and $20 \mathrm{~m}$ deep. Only about $1 \mathrm{~km}^{2}$ of proximal flows exposed; source vent surrounded by flows from relatively younger lava fields. The rock is gray and has a dense matrix; it contains rare plagioclase crystals $\leq 2 \mathrm{~mm}$ and glomerophyric clots of olivine as much as $4 \mathrm{~mm}$ diameter. No paleomagnetic data. Part of Claasen vent complex, correlation based on location and similar depth of loess and eolian sand

Qwfb6 Basaltic pahoehoe lava flows and near-vent pyroclastic deposits of the Vent 4829 lava field-Vent area is a N. $10^{\circ} \mathrm{W}$.-oriented elongated slot about $3 \mathrm{~m}$ deep and $100 \mathrm{~m}$ long. Vent rimmed by reddish, oxidized pyroclastic deposits. A rootless (?) satellite vent surrounded by pyroclastic deposits is located about $600 \mathrm{~m}$ east of the main vent. Medial and distal flows mantled by $\leq 2 \mathrm{~m}$ loess and eolian sand, which is farmed. Rock is dark gray, fine grained, and contains plagioclase phenocrysts $\leq 2 \mathrm{~mm}$, olivine crystals $\leq 1 \mathrm{~mm}$, and glomerophyric clots of olivine crystals as large as $6 \mathrm{~mm}$ diameter. Part of Claasen vent complex, based on paleomagnetic correlation

Qwfb7 Basaltic near-vent pyroclastic deposits and medial and distal pahoehoe lava flows of the Vent 4801 lava field - Vent area is eruptive fissure about $600 \mathrm{~m}$ long bordered by reddish, oxidized, bedded cinders and scoria exposed in road cut. Medial and distal flows are mantled by $\leq 2 \mathrm{~m}$ loess, which is farmed. Rock is dark gray, has a fine- to medium-grained matrix, and contains plagioclase $\leq 4 \mathrm{~mm}$, olivine $\leq 2 \mathrm{~mm}$, and 
glomerophyric clots of plagioclase + olivine $\leq 6 \mathrm{~mm}$ diameter. ${ }^{40} \mathrm{Ar} /{ }^{39} \mathrm{Ar}$ age is $68 \pm 8 \mathrm{ka}$. Part of Claasen vent complex

Qwfb8 Basaltic near-vent pyroclastic deposits and medial and distal pahoehoe lava flows of the Vent 4862 lava field-Vent area is a high-standing ( $12 \mathrm{~m}$ above surrounding terrane), north-south elongated ridge having two source vents about $400 \mathrm{~m}$ apart. Pyroclastic materials present but in small volume near vents. Medial and distal flows mantled by $\leq 2 \mathrm{~m}$ loess and eolian sand, but farmed. Rock is dark gray, has a fine- to medium-grained matrix, and phenocrysts of plagioclase $\leq 5 \mathrm{~mm}$, olivine $\leq 2 \mathrm{~mm}$, and moderately abundant glomerophyric clots of olivine $\leq 10 \mathrm{~mm}$ diameter. Part of Claasen vent complex based on paleomagnetic correlation

Qwfb9 Basaltic near-vent pyroclastic deposits and medial and distal pahoehoe lava flows of the Vent 4835 lava field - Vent area consists of a single circular depression $100 \mathrm{~m}$ diameter. Pyroclastic materials present but in small volume near vent. Medial and distal flows mantled by $\leq 2 \mathrm{~m}$ loess and eolian sand, but farmed. Rock is dark gray, fine- to medium-grained, and contains distinctive glomerophyric clots of olivine+plagioclase $\leq 7 \mathrm{~mm}$. Part of Claasen vent complex based on paleomagnetic correlation

Qwfb10

Basaltic near-vent pyroclastic deposits and proximal pahoehoe lava flows of the Vent 4569 lava field - Vent area surrounded by flows of younger lava fields. Mantled by loess $\leq 3 \mathrm{~m}$, but farmed. Part of Claasen vent complex; correlation based on location and similar depth of loess and eolian sand

\section{INFERNO CHASM VENT COMPLEX (LATE PLEISTOCENE)}

The Inferno Chasm vent complex is an eruptive-fissure system that includes, from north to south, the Horse Butte (Qsbb25), Cottrells Blowout (Qwfb14), Inferno Chasm (Qwfb12), East Inferno Chasm (Qwfb13), and Vent 5094 (Qsbb24) lava fields. All lava fields in this eruptive-fissure system have the same paleomagnetic direction (table 1), indicating that they all formed in the same eruptive pulse about $73 \pm 8 \mathrm{ka}$ (see description for Horse Butte lava field (Qsbb25) for age). Overlapping relationships among flows indicate that eruptions began at Cottrells Blowout, migrated north to Horse Butte, then south to the Inferno Chasm vents, and ended at Vent 5094

Qsbb24 Basaltic pahoehoe lava flows and minor near-vent pyroclastic deposits of the Vent 5094 lava field-Vent area for Vent 5094 is a north-south elongated, $500 \mathrm{~m}$-long, eruptivefissure. Two small vent depressions about $100 \mathrm{~m}$ northwest and southwest of hill 5108 are believed to be bocca vents to the main eruptive fissure. The largest volume of the Vent 5094 eruption occurred at these two vents. Two lava ponds, each about $1.5 \mathrm{~km}$ long and $500 \mathrm{~m}$ wide extend, northwest and southwest from the vents at hill 5108 . The lava ponds have steep leveed margins as high as $10 \mathrm{~m}$. These lava ponds are known informally as the Papadakis perched lava ponds. Reddish, oxidized pyroclastic deposits occur both on hill 5094 and hill 5108. Pahoehoe flows from the bocca vents traveled westward and lapped onto two high-standing areas of lava-tubes of the Horse Butte lava field (Qsbb25). Medial and distal flows are rough and contain jumbled slabs of pahoehoe and steep flow fronts as high as $8 \mathrm{~m}$. Relief on medial and distal flows is $\leq 15 \mathrm{~m}$. Rock is dark gray, contains small phenocrysts of plagioclase $\leq 3 \mathrm{~mm}$ and olivine $\leq 1.5 \mathrm{~mm}$, and glomerophyric clots of plagioclase+olivine about $5 \mathrm{~mm}$ diameter.

Qwfb12 Basaltic, pahoehoe lava flows and near-vent deposits of the Inferno Chasm lava fieldMain vent is a roughly circular depression about $200 \mathrm{~m}$ diameter, $30 \mathrm{~m}$ deep, having steep to vertical walls. A lava channel about $100 \mathrm{~m}$ wide and as much as $20 \mathrm{~m}$ deep has steep walls. The lava channel, called Inferno Chasm, extends about $1.5 \mathrm{~km}$ west and southwest of the vent area. At its terminus, the channel is overlapped by flows from Vent 5094 (Qsbb24) lava field, indicating relative age relationships. Proximal deposits are mainly thin, shelly pahoehoe flows, medial flows are relatively smooth pahoehoe. Rock is gray, has a fine-grained matrix, and contains abundant phenocrysts of plagioclase $\leq 3 \mathrm{~mm}$ and olivine $\leq 3 \mathrm{~mm}$, and abundant glomerophyric clots of olivine+plagioclase crystals as large as $5 \mathrm{~mm}$ diameter

Qwfb13 Basaltic pahoehoe lava flows and near-vent pyroclastic deposits of the East Inferno Chasm lava field - Vent area consists of two, roughly circular, shallow depressions, 
each about $25 \mathrm{~m}$ diameter. Vents aligned about N. $10^{\circ} \mathrm{W}$. Vent area has smooth slopes consisting of oxidized pyroclastic deposits. Medial and distal flows are relatively smooth pahoehoe. Flows lap onto flows of Horse Butte lava field (Qsbb25) about $1.5 \mathrm{~km}$ northeast of the northernmost vent. Rock is dark gray, and contains moderately abundant phenocrysts of plagioclase $\leq 4 \mathrm{~mm}$ and olivine $\leq 1.5 \mathrm{~mm}$. Glomerophyric clots of olivine+plagioclase are $\leq 4 \mathrm{~mm}$

Qsbb25

Qwfb14

Qwfb15
Basaltic pahoehoe lava flows and near-vent pyroclastic deposits of the Horse Butte lava field-Vent area for flows at Horse Butte is located about $2 \mathrm{~km}$ north of Cottrells Blowout and $1 \mathrm{~km}$ north of the northern boundary of this quadrangle. The vent area consists of a north-south trending 1.1-km long, 700-m wide, 90-m deep crater at the top of a large shield volcano. Vent crater is one of the largest and deepest in the eastern Snake River Plain. Crater contains several nearly horizontal terraces, indicating that piston-like filling and draining and lava-lake activity occurred during the later stages of vent development. A tube-skylight system in Horse Butte flows, called the Bear Trap lava tube system, extends across the northern margin of this map for a distance of about $35 \mathrm{~km}$. Many skylights of the tube system are accessible by roads. Medial flows contain many tumuli, pressure ridges, and pressure plateaus. Flows from rootless vents along the tube system are extremely smooth; local relief is $\leq 0.5 \mathrm{~m}$. Dashed contact in unit separates flows from two adjacent lava-tube systems. Map units Qsbb36 and Qsbc22 that occur as kipukas in the Craters of the Moon lava field of the geologic map of the Craters of the Moon quadrangle (Kuntz and others, 2007) are now believed to be parts of the Horse Butte lava field (Qsbb25). Basaltic lava flows of the Horse Butte lava field cover an estimated area of about $500 \mathrm{~km}^{2}$ in this quadrangle and about $180 \mathrm{~km}^{2}$ in the Craters of the Moon quadrangle to the north. The total volume of the Horse Butte lava field is estimated to be about $6 \mathrm{~km}^{3}$. Proximal flows are typically dark gray, contain phenocrysts of plagioclase $\leq 6 \mathrm{~mm}$ and olivine $\leq 2 \mathrm{~mm}$ in a matrix of minerals all $\leq 0.5 \mathrm{~mm}$. Glomerophyric clots of plagioclase and plagioclase + olivine are typically $\leq 5 \mathrm{~mm}$. Flows mantled by $\leq 2 \mathrm{~m}$ loess and eolian sand. ${ }^{40} \mathrm{Ar} /{ }^{39} \mathrm{Ar}$ age is $73 \pm 8 \mathrm{ka}$ (table 2)

Near-vent pyroclastic deposits and proximal pahoehoe lava flows of the Cottrells Blowout lava field-Slot-shaped vent trending about $\mathrm{N} .15^{\circ} \mathrm{W}$. is one of the most spectacular in terms of depth and length in the eastern Snake River Plain. Vent is $600 \mathrm{~m}$ long, about $200 \mathrm{~m}$ wide, and as deep as $50 \mathrm{~m}$. Walls of vent are steep to vertical. Flows exposed in vent walls are mainly shelly pahoehoe. Flows to east and south of vent were fed from a lava channel. Proximal flows mantled by thin $(\leq 1 \mathrm{~m})$ pyroclastic deposits from younger, nearby vents. Flows from Cottrells Blowout have limited distribution; they are lapped onto by flows from Horse Butte (Qsbb25) and Vent 5094 (Qsbb24). Rock is gray, has a fine- to medium-grained matrix where crystals are $\leq 0.5 \mathrm{~mm}$ and contains moderately abundant phenocrysts of plagioclase $\leq 4 \mathrm{~mm}$ and olivine $\leq 1.5 \mathrm{~mm}$. Glomerophyric clots of olivine+plagioclase are $\leq 4 \mathrm{~mm}$

Basaltic, near-vent and proximal, medial, and distal pahoehoe lava flows of the Wapi Park lava field (late Pleistocene) —Elongated vent area is a set of about 10, roughly circular depressions oriented about N. $15^{\circ}$ E. Each depression is about $200-400 \mathrm{~m}$ diameter. The vent depressions occur over a distance of $2 \mathrm{~km}$ in Wapi Park. A complex lava pond having numerous irregular embayments is present at the northeast end of the vent alignment. Southwest part of vent alignment overlapped by flows of the Wapi lava field (Qwfa2; 2,270 $\pm 50{ }^{14} \mathrm{C}$ yr B.P., Kuntz, Spiker, and others, 1986). Vent area stands about $30-35 \mathrm{~m}$ above surrounding proximal flows. Proximal pahoehoe flows are bulbous, having local relief of $\leq 3 \mathrm{~m}$; pyroclastic deposits are rare in the vent area. Medial flows are covered by flows of the Wapi lava field (Qwfa2; $2,270 \pm 50{ }^{14} \mathrm{C}$ yr B.P., Kuntz, Spiker, and others, 1986). A prominent lava-tube system with numerous skylights, perched lava ponds, and irregular depressions extends west and southwest for a distance of about $13 \mathrm{~km}$ from where the flows of the Wapi Park lava field emerge from beneath the Wapi lava field (Qwfa1).

Pahoehoe flows in the tube-fed lobe have smooth surfaces; local relief is $\leq 0.5 \mathrm{~m}$. Distal flows of the Wapi Park lava field extend about $30 \mathrm{~km}$ southwest of the source vents in Wapi Park. Distal flows range from dense rock in which all crystals 
are $\leq 0.5 \mathrm{~mm}$ to fine-grained rock containing larger crystals of plagioclase and olivine $\leq 1.5 \mathrm{~mm}$ in a dense matrix. Vents in Wapi Park are believed to be at the northeast end of a N.15 E.-N.30 E.-trending volcanic rift zone that extends southwest through Vent 4901 (Qwfb16) to Higgins Blowout (Qwfc3; 289 5 ka, table 1) along the southwest margin of the Wapi lava field. ${ }^{40} \mathrm{Ar} /{ }^{39} \mathrm{Ar}$ age is $87 \pm 9 \mathrm{ka}$ (table 1)

Qwfb16

Qwfb17

Near-vent, basaltic pyroclastic deposits of the Vent 4901 lava field (late Pleistocene) Vent area is a kipuka surrounded by pahoehoe flows of the Wapi lava field (Qwfa2; $2,270 \pm 50{ }^{14} \mathrm{C}$ yr B.P., Kuntz, Spiker, and others, 1986). Unit not studied in the field; examination of air photos and topographic map shows two circular vent depressions aligned N. $15^{\circ}$ E., on strike with vents in Wapi Park. Southernmost depression filled by pahoehoe flows of Wapi lava field. Age assignment based on vent alignment and assumption that Vent 4901 lava field formed simultaneously with Wapi Park lava field

Basaltic near-vent pyroclastic deposits and pahoehoe lava flows of the Kimama Butte lava field - Lava field is a large shield volcano rising about $160 \mathrm{~m}$ above surrounding lava fields. Vent area consists of a north-south, 700-m long, 200-m wide depression surrounded by basalt parapets as high as $50 \mathrm{~m}$ on east, south, and west sides. A circular pit crater, about $200 \mathrm{~m}$ diameter and $15 \mathrm{~m}$ deep, is at the northern end of the vent area. Vent area mantled chiefly by shelly pahoehoe flows, pyroclastic deposits are rare. Medial and distal flows are mainly tube-fed pahoehoe having local relief of $\leq 2 \mathrm{~m}$. Lava field has an area of about $250 \mathrm{~km}^{2}$ and contains about $8 \mathrm{~km}^{3}$ of flows. Flows mantled by loess and eolian sand $\leq 2 \mathrm{~m}$ only locally. Not farmed in most areas. Rock is light gray, diktytaxitic, and ranges from very fine (all crystals $\leq 1 \mathrm{~mm}$ ) to medium grained in which plagioclase and olivine crystals are $\leq 2 \mathrm{~mm} .{ }^{40} \mathrm{Ar} /{ }^{39} \mathrm{Ar}$ age is $87 \pm 11 \mathrm{ka}$ (table 1)

Qsbb14 Basaltic medial and distal pahoehoe lava flows of the Black Ridge Crater lava field (late Pleistocene) - Vent area is located in Craters of the Moon map area about $3 \mathrm{~km}$ northeast of the northwest corner of this quadrangle (Kuntz and others, 2007). Medial and distal flows of the southern part of lava field exposed in northwest corner of this quadrangle. Medial and distal pahoehoe flows have prominent lava-tube and skylight systems. Flows characterized by many tumuli, pressure ridges and pressure plateaus, having local relief of $\leq 5 \mathrm{~m}$. Flows are mantled locally by $\leq 2 \mathrm{~m}$ loess and eolian sand; most areas free of loess and sand. Rock is moderately coarse grained, containing plagioclase and olivine phenocrysts $\leq 5 \mathrm{~mm}$ in a matrix of minerals $\leq 1 \mathrm{~mm}$. Relative age inferred from stratigraphic relations with dated, nearby lava fields, estimated age about $120 \mathrm{ka}$ (Kuntz and others, 2007)

Qsbb34

Basaltic near-vent pyroclastic deposits and medial and distal pahoehoe lava flows of the Vent 5329 lava field (late Pleistocene) - Vent area is 200-m long, roughly circular, shallow depression. A major lava tube extends east and southeast of the vent. A secondary vent is located about $1.5 \mathrm{~km}$ southeast of main vent; it may be a rootless vent or a vent aligned with the main vent. If the latter, the two vents define a N.30 W.trending eruptive-fissure system. The two vents in this quadrangle are aligned with two vents several kilometers farther north in the Craters of the Moon quadrangle. Rock not studied in the field. Age approximately $210 \mathrm{ka}$ (Kuntz and others, 2007)

\section{ERUPTIVE PERIOD C}

Qwf1 Near-vent pyroclastic deposits and distal pahoehoe lava flows of the Split Butte lava field (late middle Pleistocene) - Split Butte is a tuff cone or maar formed by a phreatomagmatic eruption. The vent area is roughly circular, $600 \mathrm{~m}$ diameter, and consists of a tephra ring containing an inner lava pond. Tuff cone consists chiefly of reddish brown, olive green, and black vitric ash. The margins of the lava pond are preserved as a narrow shelf of basalt; the central part of the lava pond has subsided forming a pit crater $400 \mathrm{~m}$ diameter and $20 \mathrm{~m}$ deep. Partial palagonitization of sideromelane, near lack of vesicles, accretionary lapilli, plastic deformation of layers under ejecta blocks, and the presence of abundant secondary minerals such as calcite and zeolites all suggest phreatomagmatic origin for Split Butte. Definitive study of Split Butte is by Womer and others (1982). Area of pahoehoe flows (QwfC2) about $15 \mathrm{~km}$ southwest is tentatively correlated to source vent at Split Butte by paleomagnetic data (table 2). ${ }^{40} \mathrm{Ar} /{ }^{39} \mathrm{Ar}$ age is $138 \pm 6 \mathrm{ka}$ (table 1) 
Qwfc2 Basaltic, distal pahoehoe flows (late middle Pleistocene) - Flows are smooth and consist of dense, fine-grained rock in which all crystals are $\leq 1 \mathrm{~mm}$. May be correlated to source vent at Split Butte on the basis of similarity in paleomagnetic directions

Qsbc22 Basaltic pahoehoe flows of the Vent 4645 lava field (late middle Pleistocene) - Surface-, channel-, and tube(?)-fed, dark-gray and medium-gray, pahoehoe basalt flows, and red, oxidized, and black, near-vent pyroclastic deposits. Vent area is located about $7 \mathrm{~km}$ north of the northern boundary of this map in the Craters of the Moon $30^{\prime} \times 60^{\prime}$ quadrangle (Kuntz and others, 2007). Vent area is a N. $5^{\circ} \mathrm{W}$.-trending, fissure-dominated, 1-km-long, slot-shaped, shallow ( $\leq 15 \mathrm{~m}$ deep) depression atop a broad lava cone that is about $50 \mathrm{~m}$ above surrounding, younger flows. Distal and medial flows have smooth surfaces; local relief $\leq 2 \mathrm{~m}$. Rock examined is unique: olivine phenocrysts are larger $(\leq 3 \mathrm{~mm})$ than plagioclase phenocrysts $(\leq 1.5 \mathrm{~mm})$. Phenocrysts are set in a fine matrix of crystals $\leq 0.5 \mathrm{~mm}$. Cumulophyric clots of as many as 4 olivine crystals and clots of as many as 20 plagioclase and 20 olivine crystals are common. Most large olivine crystals are euhedral, $\leq 1.5 \mathrm{~mm}$, and many are skeletal, containing vacuoles filled by glass. Flows are mantled by $\leq 2 \mathrm{~m}$ of loess and eolian sand

Qsbc52 Distal pahoehoe flows of the Mosby Butte lava field (late middle Pleistocene)—Very small area $\left(<1 \mathrm{~km}^{2}\right)$ of distal pahoehoe lava flows of the Mosby Butte lava field (Kuntz and others, 2007) at northern border of this map. Flows characterized by many tumuli, pressure plateaus, and pressure ridges. Rock is porphyritic containing plagioclase $(\leq 5 \mathrm{~mm})$ and olivine $(\leq 1.5 \mathrm{~mm})$ crystals in a matrix in which crystals are $\leq 0.3 \mathrm{~mm}$. Cumulophyric clots of as many as 20 olivine crystals and olivine+plagioclase crystals are common. ${ }^{40} \mathrm{Ar} /{ }^{39} \mathrm{Ar}$ age is $265 \pm 30 \mathrm{ka}$ (Kuntz and others, 2007)

Qwfc3 Basaltic, near-vent pyroclastic deposits and proximal and medial pahoehoe lava flows of the Higgins Blowout lava field (late middle Pleistocene) - Vent is a 600-m-long, 200 -m-wide, slot-shaped depression oriented about N. $40^{\circ}$ E., roughly parallel to and on trend with the vent system in Wapi Park lava field (Qwfb15). Slot is as deep as $50 \mathrm{~m}$. Vent walls are steep and consist of shelly pahoehoe and minor amounts of pyroclastic material. A prominent, 400-m-wide, 1.5-km-long, leveed channel extends southwest from the vent area. Levees are about $5 \mathrm{~m}$ high. Proximal pahoehoe flows are very rough surfaced and hummocky, verging on a'a. Rock is dark gray, fine grained, and contains small crystals of plagioclase and olivine both $\leq 2 \mathrm{~mm}$ in longest dimension. Glomerophyric clots of olivine+plagioclase as large as $8 \mathrm{~mm}$ are rare. $\mathrm{K}-\mathrm{Ar}$ age is $289 \pm 5 \mathrm{ka}$ (table 1)

\section{FLAT TOP VENT COMPLEX (LATE MIDDLE PLEISTOCENE)}

The Flat Top vent complex consists of five contiguous lava fields that extend from the vent for the

Rock Lake lava field in the Craters of the Moon quadrangle south to the Vent 4822 lava field (Qwfc6). All have the same paleomagnetic direction, suggesting that they all formed within a short period of time, perhaps a hundred years or less. ${ }^{40} \mathrm{Ar} /{ }^{39} \mathrm{Ar}$ age of the Rock Lake Lava field, part of the Flat Top Vent complex, is $290 \pm 50 \mathrm{ka}$ (Kuntz and others, 2007). This age applies to all lava fields of the Flat Top vent complex

Qwfc4 Basaltic, near-vent pyroclastic and proximal, medial, and distal pahoehoe flows of the

Flat Top lava field-Flat Top is a broad lava dome, having a vent area largely covered by shelly pahoehoe and reddish, oxidized cinders. The vent is marked by a shallow $(\leq 5 \mathrm{~m})$, roughly circular depression that is about $100 \mathrm{~m}$ wide. A roughly circular lava pond, about $0.5 \mathrm{~km}$ in longest dimension, is about $0.5 \mathrm{~km}$ southeast of the vent area. A second lava pond, $0.2 \mathrm{~km}$ diameter, is $1.1 \mathrm{~km}$ southeast of the vent area. Rock is dark gray, has a fine-grained matrix, contains crystals of plagioclase $\leq 5 \mathrm{~mm}$, olivine crystals $\leq 2 \mathrm{~mm}$, and glomerophyric clots of plagioclase+olivine as large as $10 \mathrm{~mm}$ diameter

Qwfc5 Basaltic, near-vent pyroclastic and proximal, medial, and distal pahoehoe lava flows of the Vent 5026 lava field - Vent area is a northeast-elongated ridge having a shallow vent depression. Vent area surrounded by shelly pahoehoe flows and minor pyroclastic deposits. Medial and distal flows are smooth pahoehoe. Rock is dark gray, has a fine-grained matrix, and contains plagioclase crystals $\leq 3 \mathrm{~mm}$, olivine crystals $\leq 1 \mathrm{~mm}$, and rare glomerophyric clots of plagioclase + olivine crystals $\leq 6 \mathrm{~mm}$. Part of Flat Top vent complex 
Qwfc6 Basaltic, near-vent pyroclastic and proximal, medial, and distal pahoehoe lava flows of the Vent 4822 lava field - Vent area is a low mound about $400 \mathrm{~m}$ across. Shelly pahoehoe is prominent at vent, pyroclastic deposits are minor. Medial and distal flows are smooth pahoehoe. Rock is dark gray, has a fine-grained matrix, contains plagioclase crystals $\leq 3 \mathrm{~mm}$, all olivine crystals are $\leq 1 \mathrm{~mm}$, and contains rare glomerophyric clots of plagioclase + olivine $\leq 3 \mathrm{~mm}$. Part of Flat Top vent complex

Qsbc53 Distal basaltic pahoehoe flows of the Vent 5083 lava field-Distal pahoehoe basalt flows from Vent 5083, approximately $1 \mathrm{~km}$ north of northern boundary of this quadrangle, in Craters of the Moon quadrangle. Flows mostly covered by alluvial deposits, loess, and eolian sand. Part of Flat Top vent complex

Qsbc59 Basaltic, near-vent pyroclastic and proximal, medial, and distal pahoehoe lava flows of the Streifling lava field-Surface-, channel-, and tube (?)-fed, dark-gray and medium gray, pahoehoe flows, shelly pahoehoe, and red, oxidized, and black, near-vent pyroclastic deposits. Vent area is a nearly circular crater approximately $180 \mathrm{~m}$ in diameter. Crater walls are shallow; vent is $\leq 10 \mathrm{~m}$ deep. Near-vent pyroclastic deposits are exposed locally around vent area. Flows have relatively smooth surfaces; local relief is $\leq 2.5 \mathrm{~m}$. Flows mantled by $\leq 3 \mathrm{~m}$ of loess and eolian sand. Part of Flat Top vent complex

The following five map units may be part of a vent complex, but this has not been verified by paleomagnetic studies. Supposition of vent complex status is supported by close proximity of vents and similar thickness of loess cover, suggesting close or similar ages for the five map units.

Qwfc7 Basaltic, near-vent pyroclastic and proximal, medial, and distal pahoehoe lava flows of the Vent 4753 lava field (late middle Pleistocene) — Vent area mantled by relatively thick loess and eolian sand $\leq 5 \mathrm{~m}$ thick. Identified mainly by topographic signature. Lava field almost entirely covered by farmed land. Not studied in field

Qwfc8 Basaltic, near-vent pyroclastic and proximal, medial, and distal pahoehoe lava flows of the Vent 4754 lava field (late middle Pleistocene) - Vent area mantled by relatively thick loess and eolian sand $\leq 5 \mathrm{~m}$ thick; identified mainly by topographic signature. Rock is gray, matrix contains crystals $\leq 1 \mathrm{~mm}$, plagioclase crystals $\leq 2 \mathrm{~mm}$, olivine crystals $\leq 1 \mathrm{~mm}$, and rare glomerophyric clots of plagioclase + olivine $\leq 3 \mathrm{~mm}$ diameter. Lava field almost entirely covered by farmed land

Qwfc9 Basaltic, near-vent pyroclastic and proximal, medial, and distal pahoehoe lava flows of the Vent 4705 lava field (late middle Pleistocene) - Vent area mantled by relatively thick loess and eolian sand $\leq 5 \mathrm{~m}$ thick; identified mainly by topographic signature. Lava field almost entirely covered by farmed land. Not studied in field

Qwfc10 Basaltic, near-vent pyroclastic and proximal, medial, and distal pahoehoe lava flows of the Vent 4644 lava field (late middle Pleistocene) — Vent area mantled by relatively thick loess and eolian sand $\leq 5 \mathrm{~m}$ thick; identified mainly by topographic signature. Lava field almost entirely covered by farmed land. Not studied in field

Qwf11 Basaltic, near-vent pyroclastic deposits and proximal, medial, and distal pahoehoe lava flows of the Vent 4539 lava field (late middle Pleistocene) - Vent area mantled by relatively thick loess and eolian sand $<5 \mathrm{~m}$ thick; identified mainly by topographic signature. Surrounded by flows of the Wapi lava field (Qwfa2; 2,270 $\pm 50{ }^{14} \mathrm{C}$ yr B.P., Kuntz, Spiker, and others, 1986) on west, south, and east sides. Lava field almost entirely covered by farmed land. Not studied in field

\section{ERUPTIVE PERIOD D}

Qwfd1 Basaltic near-vent pyroclastic deposits, proximal, medial and distal pahoehoe lava flows of the Adelaide Butte lava field (early middle Pleistocene)-The Adelaide Butte lava field is a large shield volcano covering an area of about $315 \mathrm{~km}^{2}$ and has a volume of about $3-5 \mathrm{~km}^{3}$. About $250 \mathrm{~km}^{2}$ of the lava field lie within the boundaries of this map. The vent is a shallow, slightly elongated, N. $10^{\circ} \mathrm{W}$.-trending depression about $500 \mathrm{~m}$ long and $10 \mathrm{~m}$ deep. Black cinders, agglomerate, and welded spatter are scattered near the vent. The vent crown lies about $75 \mathrm{~m}$ above the surrounding plateau of pahoehoe flows. Two prominent lava-tube systems having numerous rootless vents 
extend north and east from the vent depression. Rock in distal flows is dark gray, dense; plagioclase crystals are $\leq 1 \mathrm{~mm}$, and olivine crystals are $\leq 3 \mathrm{~mm}$. The dense matrix and near lack of phenocrysts in distal flows suggest rapid transport of lava through lava tubes. Medial and distal flows covered by $\leq 7 \mathrm{~m}$ loess; region is extensively farmed. ${ }^{40} \mathrm{Ar} /{ }^{39} \mathrm{Ar}$ age is $475 \pm 38 \mathrm{ka}$ (table 1 )

Qwfd2

Qwfd3

Qwfd4

Qwfd5

Qwfd6

Qwfd7
Basaltic proximal, medial and distal pahoehoe lava flows of the Vent 4659 lava field (early middle Pleistocene) — Vent is roughly circular depression about $500 \mathrm{~m}$ diameter and $7 \mathrm{~m}$ deep. Vent lies at northern part of a 6-km-long, 3 to $5 \mathrm{~km}$-wide lava ridge; only western half of ridge exposed in this quadrangle. Vent area and pahoehoe flows covered by thick loess $\leq 7 \mathrm{~m}$ deep; region heavily farmed. Rock is dark gray, has a fine, granular matrix, all plagioclase crystals are $\leq 1 \mathrm{~mm}$, olivine crystals are $\leq 3 \mathrm{~mm}$, and glomerophyric clots of olivine are $\leq 6 \mathrm{~mm}$. Age assumed to be same as Vent 4640 (Qwfd3) lava field because the two fields appear to be part of the same lava ridge that formed from a single eruptive fissure

Basaltic proximal, medial and distal pahoehoe lava flows of the Vent 4640 lava field (early middle Pleistocene)—Roughly circular depression about $500 \mathrm{~m}$ diameter and $10 \mathrm{~m}$ deep marks vent for lava field. Vent area and pahoehoe flows covered by thick loess $\leq 7 \mathrm{~m}$ deep; region heavily farmed. Rock is dark gray, matrix is dense, contains abundant olivine crystals $\leq 2 \mathrm{~mm}$, and glomerophyric clots of olivine crystals $<6 \mathrm{~mm}$. Vent lies in central part of a 6-km-long, 3 to $5 \mathrm{~km}$-wide lava ridge; only western half of ridge exposed in this quadrangle. ${ }^{40} \mathrm{Ar} /{ }^{39} \mathrm{Ar}$ age is $690 \pm 50 \mathrm{ka}$ (table 2)

Basaltic near-vent pyroclastic deposits and proximal pahoehoe lava flows of The Crater lava field (early middle Pleistocene) - The Crater is a large lava cone that rises about $100 \mathrm{~m}$ above surrounding, younger lava flows. The vent is a circular depression about $500 \mathrm{~m}$ wide and $30 \mathrm{~m}$ deep. The lava cone is mantled by scoriaceous flows, welded spatter and cinders; the interior of the vent displays numerous, thin, shelly pahoehoe flows. Rock exposed in crater walls is light gray, diktytaxitic, fine grained, and has plagioclase $\leq 1.5 \mathrm{~mm}$, olivine $\leq 1.5 \mathrm{~mm}$, and glomerophyric clots of olivine+plagioclase as large as $6 \mathrm{~mm}$. A thin strip of proximal and medial pahoehoe flows exposed between younger enclosing flows of the Kimama Butte lava field extends southeast from the base of the lava cone for about $4 \mathrm{~km}$ to near the southern boundary of this map. Medial pahoehoe flows are dark gray, dense, all plagioclase is $\leq 1 \mathrm{~mm}$, and conspicuous olivine phenocrysts are $\leq 3 \mathrm{~mm}$. Lava flows have normal magnetic polarity (table 2) so are younger than $780 \mathrm{ka}$ but are older than overlying lava

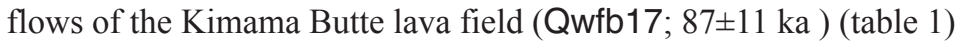

Basaltic near-vent pyroclastic deposits and proximal pahoehoe lava flows of the Vent 4401 lava field (early middle Pleistocene) - Low lava cone that rises about $30 \mathrm{~m}$ above surrounding flows. Vent area is a shallow depression about $700 \mathrm{~m}$ across, about $10 \mathrm{~m}$ deep, and open to the northwest. Vent area and flows mantled by $\leq 7 \mathrm{~m}$ loess, extensively farmed. Rock is dark gray, fine- to medium-grained, contains moderately abundant plagioclase $\leq 6 \mathrm{~mm}$, rare olivine $\leq 2 \mathrm{~mm}$, and glomerophyric clots of plagioclase $\leq 10 \mathrm{~mm}$. Normal magnetic polarity (table 2). Overlapped by flows from Wapi

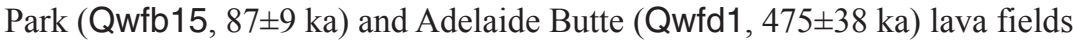
Near-vent pyroclastic deposits and proximal and medial pahoehoe lava flows of the Vent 4429 lava field (early middle Pleistocene) - Vent area is a roughly circular depression about $300 \mathrm{~m}$ diameter, about $10 \mathrm{~m}$ deep, open to the west. Vent area and flows mantled by $\leq 7 \mathrm{~m}$ loess, and extensively farmed. Rock is dark gray, fine- to medium-grained, contains abundant plagioclase $\leq 6 \mathrm{~mm}$, olivine crystals $\leq 2 \mathrm{~mm}$, and glomerophyric clots of plagioclase+olivine. Lava flows have normal magnetic polarity (table 2) thus younger than $780 \mathrm{ka}$ and are overlapped by flows of Adelaide Butte lava field (Qwfd1, 475 $38 \mathrm{ka}$, table 1)

Basaltic near-vent pyroclastic deposits and proximal pahoehoe lava flows of the Vent 4371 lava field (early middle Pleistocene) - Vent area is low lava cone of pyroclastic materials about $20 \mathrm{~m}$ high. Pahoehoe flows covered by loess $\leq 3 \mathrm{~m}$ thick. Lava cone overlapped on east by flows of Horse Butte lava field (Qsbb25, 73 $\pm 8 \mathrm{ka}$, table 1) and on south by flows of Adelaide Butte lava field (Qwfd1, $475 \pm 38$ ka, table 1). Rock 
is dark gray, fine grained, and contains plagioclase crystals $\leq 3 \mathrm{~mm}$, olivine crystals $\leq 2 \mathrm{~mm}$, and rare glomerophyric clots of olivine+plagioclase. Lava flows have normal magnetic polarity (table 2) thus are younger than $780 \mathrm{ka}$ and are overlapped by flows of Adelaide Butte lava field ( $475 \pm 38 \mathrm{ka})$

Qwfd8

Basaltic, near-vent pyroclastic deposits and proximal pahoehoe lava flows of the Vent 4267 lava field (early middle Pleistocene) - Vent area is a low lava cone that rises about $20 \mathrm{~m}$ above surrounding lava fields. Reddish, oxidized cinders at vent area. Proximal flows mantled by loess $\leq 5 \mathrm{~m}$ thick. Rock has reddish-gray, fine-grained matrix, olivine crystals $\leq 2 \mathrm{~mm}$, plagioclase crystals $\leq 7 \mathrm{~mm}$, and glomerophyric clots of olivine+plagioclase $\leq 10 \mathrm{~mm}$. Covered by flows from Adelaide Butte lava field (Qwfd1, $475 \pm 38 \mathrm{ka}$, table 1) on the south. No paleomagnetic data

Qwfd9

Basaltic, near-vent pyroclastic and proximal and medial pahoehoe lava flows of the Knoll Vent lava field (early middle Pleistocene) - Vent area is a steep-sided shield volcano having a local relief of about $100 \mathrm{~m}$. Vent depression is oriented north-northwest, is about $200 \mathrm{~m}$ across, and about $10 \mathrm{~m}$ deep. Vent area thickly mantled by loess and eolian sand $\leq 10 \mathrm{~m}$ thick, extensively farmed. Lava field surrounded by flows of

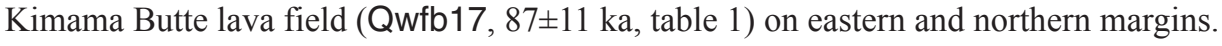
Rock is dark gray, has a fine-grained matrix in which all crystals are $\leq 1 \mathrm{~mm}$, rare plagioclase crystals $\leq 2 \mathrm{~mm}$, rare olivine crystals $\leq 1 \mathrm{~mm}$, and conspicuous glomerophyric clots of olivine+plagioclase $\leq 8 \mathrm{~mm}$ diameter. Normal magnetic polarity (table 2 ). Thick loess cover may indicate older age assignment than that given

\section{ERUPTIVE PERIOD E}

Qwfe1 Near-vent pyroclastic deposits and proximal, medial, and distal pahoehoe lava flows of the Sid Butte lava field (early Pleistocene) - Sid Butte is a moderate-sized shield volcano that covers an area of about $75 \mathrm{~km}^{2}$ in this quadrangle and about $50 \mathrm{~km}^{2}$ in the Twin Falls 1:100,000-scale quadrangle to the west. The vent rises about $180 \mathrm{~m}$ above younger lava flows from Kimama Butte $3 \mathrm{~km}$ to the southeast. Vent is a 400-m long, shallow depression $\leq 5 \mathrm{~m}$ deep. Vent is elongated N. $20^{\circ} \mathrm{W}$. Vent area mantled by significant amounts of reddish, oxidized cinders, welded spatter, and shelly pahoehoe flows. Medial and distal flows are deeply mantled by loess $\leq 5 \mathrm{~m}$ thick and extensively farmed. Rock near vent is light gray, fine-grained, and contains plagioclase and olivine crystals $\leq 2 \mathrm{~mm}$, and glomerophyric clots of plagioclase + olivine $\leq 3 \mathrm{~mm}$. Distal flows are dark gray and have the same texture and crystal sizes. ${ }^{40} \mathrm{Ar} /{ }^{39} \mathrm{Ar}$ age is $778 \pm 8 \mathrm{ka}$ (table 1). Reversed magnetic polarity

Qwfe2 Near-vent pyroclastic deposits and proximal pahoehoe lava flows of the Vent 4559 lava field (early Pleistocene)—Lava field is a broad lava shield that rises about $100 \mathrm{~m}$ above surrounding lava fields. Vent is a roughly circular depression about $1,500 \mathrm{~m}$ diameter, less than $5 \mathrm{~m}$ deep, and open to the northwest. Vent area is filled and nearvent flows are obscured by $\leq 10 \mathrm{~m}$ loess, extensively farmed. Medial pahoehoe flows are fine- to medium-grained and contain moderate amounts of plagioclase crystals $\leq 9 \mathrm{~mm}$. Overlapped by flows of Wapi Park (Qwfb15, 87 $\pm 9 \mathrm{ka}$ ) and Adelaide Butte (Qwfd1,475 $\pm 38 \mathrm{ka}$ ) lava fields. Reversed magnetic polarity

Qwfe3 Near-vent pyroclastic deposits and proximal pahoehoe lava flows of the Vent $\mathbf{4 3 7 3}$ lava field (early Pleistocene) — Lava cone about $20 \mathrm{~m}$ high; vent depression, about $3 \mathrm{~m}$ deep and $500 \mathrm{~m}$ long, is oriented north-south. The vent area and proximal and medial flows mantled by loess $<8 \mathrm{~m}$ deep; few flows are exposed. Extensively farmed. Rock is dark gray, fine-grained, contains rare olivine crystals $\leq 1 \mathrm{~mm}$, rare plagioclase crystals $\leq 2 \mathrm{~mm}$, and glomerophyric clots of plagioclase crystals $\leq 3 \mathrm{~mm}$. Remanent magnetic direction for unit is similar to that of Sid Butte (Qwfe1), which suggests they are the same age, $778 \pm 8 \mathrm{ka}$, table 1

Qwfe4 Proximal pahoehoe lava flows of the Vent 4373 lava field (early Pleistocene)-Area of deeply $(\leq 8 \mathrm{~m})$, loess-mantled flows; vent area not evident. Overlapped by flows of Kimama Butte lava field (Qwfb17) on north, east, and south sides 
None of the following map units have radiometric ages that would determine their absolute age. Some of the units have stratigraphic relations with dated lava fields; thus, their relative ages can be inferred. Where applicable, depth of loess and eolian sand has been used to determine relative age. Arrows in Correlation of Map Units show inferred age range of units

Qwfb18 Basaltic near-vent deposits of the Rattlesnake Butte lava field (late Pleistocene)—Vent area is a 300-m-long, 100-m-wide, north-south trending depression about $30 \mathrm{~m}$ deep. Only north half of vent exposed in this quadrangle. Vent area and adjacent flows mantled by eolian sand that is locally $\leq 10 \mathrm{~m}$ thick. Normal magnetic polarity

Qwfb19 Basaltic near-vent deposits and proximal pahoehoe lava flows of the Vent 4645 lava field (late Pleistocene)—Vent area is a slot-shaped depression about $200 \mathrm{~m}$ long and $50 \mathrm{~m}$ wide. Circular depression about $30 \mathrm{~m}$ diameter indents southern part of slotshaped depression. Only minor pyroclastic deposits at vent area; thin pahoehoe flows predominate. A second vent is located about $150 \mathrm{~m}$ south of the slot shaped depression. A 600-m-long, tear-drop shaped lava pond extends south from the second vent. A poorly defined lava tube having skylights and perched lava ponds is located about $2 \mathrm{~km}$ east of the lava pond. Vents of Vent 4645 and Rattlesnake Butte lava field (Qwfb18) are aligned, suggesting they may be part of the same eruptive sequence. Flows display a rough, jagged surface composed of plates of jumbled pahoehoe. Local relief is $\leq 5 \mathrm{~m}$. Flows mantled by discontinuous patches of loess and eolian sand $\leq 1 \mathrm{~m}$ thick. Near-vent pahoehoe flows are coarse grained, containing abundant plagioclase and olivine crystals $\leq 5 \mathrm{~mm}$. Discontinuous nature of loess and eolian sand deposits suggests a late Pleistocene age, but may be much older. Age assumption also applies to Rattlesnake Butte lava field (Qwfb18)

Qwfb20 Near-vent pyroclastic deposits and pahoehoe lava flows of the Vent 4757 lava field (late Pleistocene) - Vent is a kipuka pyroclastic cone about $300 \mathrm{~m}$ diameter in Wapi lava field (Qwfa2; 2,270 $\pm 50{ }^{14} \mathrm{C}$ yr B.P., Kuntz, Spiker, and others, 1986). Air photo interpretation suggests significant mantle by loess and eolian sand. Not studied in field

\section{Qwfc12 Basaltic, near-vent pyroclastic deposits of the Vent 4811 lava field (late middle}

Pleistocene)-Vent area is a N.15 $\mathrm{W}$.-trending edifice having vent-wall deposits exposed on north, northwest, southwest, and southeast flanks. Eastern part of vent area covered by flows from Kimama Butte lava field (Qwfb17; $87 \pm 11 \mathrm{ka}$, table 1). Vent walls are as high as $30 \mathrm{~m}$ above the central vent depression. Only near-vent pyroclastic deposits exposed; all flows covered by Kimama Butte flows in this quadrangle. Near-vent deposits consist of well-bedded cinders, ash, and thin, shelly pahoehoe flows. Glomerophyric clots of plagioclase and olivine are as large as $10 \mathrm{~mm}$ diameter. Covered by $\leq 7 \mathrm{~m}$ loess; extensively farmed. Deep loess cover suggests early Pleistocene age. No paleomagnetic data

Qwfc13 Basaltic near-vent pyroclastic deposits of the Vent 4354 lava field (late middle and early middle Pleistocene)—Large slot-shaped vent approximately $1.8 \mathrm{~km}$ long, $600 \mathrm{~m}$ wide, and $40 \mathrm{~m}$ deep. Only northern third of vent exposed in this quadrangle. Reddish pyroclastic deposits and mostly shelly pahoehoe flows exposed in crater walls. Rock is medium gray, has a dense matrix, contains plagioclase crystals $\leq 4 \mathrm{~mm}$, and olivine $\leq 1 \mathrm{~mm}$. No paleomagnetic data

Qwfc14 Basaltic near-vent pyroclastic deposits of the Vent 4384 lava field (late middle and early middle Pleistocene)—Small cinder cone about $700 \mathrm{~m}$ diameter and $25 \mathrm{~m}$ high. Rock at vent area consists of reddish oxidized cinders that mostly lack crystals. Cone may be part of vent system for Vent 4354 (Qwfc13) lava field. No paleomagnetic data

Qsbc60 Basaltic, near-vent pyroclastic and proximal, medial, and distal pahoehoe flows of the Vent 5270 lava field (late middle Pleistocene) - Vent 5270 lava field is a small shield volcano having a low vent depression about $300 \mathrm{~m}$ in diameter and $15-\mathrm{m}$ deep at the summit. Proximal flows are mostly shelly pahoehoe, medial and distal flows and are mostly smooth pahoehoe having $\leq 10 \mathrm{~m}$ of relief. Two prominent lava channels are on the southwest flanks of the volcano. Most flows moved west, south and east of the vent, and only marginally to the north. Rock has medium-grained texture containing moderate amounts of plagioclase $\leq 3 \mathrm{~mm}$ and olivine+plagioclase clots of $\leq 8 \mathrm{~mm}$. 


\section{References Cited}

Champion, D.E., Lanphere, M.L., Anderson, S.R., and Kuntz, M.A., 2002, Accumulation and subsidence of late Pleistocene basaltic lava flows of the eastern Snake River Plain, Idaho, in Link, P.K., and Mink, L.L., eds., Geology, hydrology, and environmental remediation-Idaho National Engineering and Environmental Laboratory, eastern Snake River Plain, Idaho: Geological Society of America Special Paper 353, p. 175-192.

Champion, D.E., and Shoemaker, E.M., 1977, Paleomagnetic evidence for episodic volcanism on the Snake River Plain [abs.], in Greeley, R., ed., Abstracts for the planetary geology field conference on the Snake River Plain, Idaho: National Aeronautics and Space Administration Technical Memorandum 78,436, p. 7-9.

Coe, R.S., Gromme, S., and Mankinen, E.A., 1978, Geomagnetic paleointensities from radiocarbon-dated lava flows on Hawaii and the question of the Pacific nondipole low: Journal of Geophysical Research, v. 83, p. 1740-1756.

Covington, H.R., 1977, Preliminary geologic map of the Pillar Butte, Pillar Butte NE, Pillar Butte SE, and Rattlesnake Butte quadrangles, Bingham, Blaine, and Power counties, Idaho: U.S. Geological Survey Open-File Report 77-779, scale 1:48,000. [Also available at https://pubs.er.usgs.gov/ publication/ofr77779.]

Dalrymple, G.B., and Duffield, W.A., 1988, High precision ${ }^{40} \mathrm{Ar} /{ }^{39} \mathrm{Ar}$ dating of Oligocene rhyolites from the MogollonDatil volcanic field using a continuous laser system: Geophysical Research Letters, v. 15, p. 463-466.

Fleck, R.J., Sutter, J.F., and Elliott, D.H., 1977, Interpretation of discordant ${ }^{40} \mathrm{Ar} /{ }^{39} \mathrm{Ar}$ age-spectra of Mesozoic tholeiites from Antarctica: Geochimica et Cosmochimica Acta, v. 41, p. $15-32$.

Gans, P.B., 1997, Large-magnitude Oligo-Miocene extension in southern Sonora-Implications for the tectonic evolution of northwest Mexico: Tectonics, v. 16, no. 3, p. 388-408.

Greeley, R., 1982, The style of basaltic volcanism in the eastern Snake River Plain, Idaho, in Bonnichsen, B., and Breckenridge, R.M., eds., Cenozoic Geology of Idaho: Idaho Bureau of Mines and Geology Bulletin 26, p. 407-421. [Now the Idaho Geological Survey]

King, J.S., 1977, Crystal Ice Cave and Kings Bowl Crater, eastern Snake River Plain, Idaho, in Greeley, R., and King, J.S., eds., Volcanism of the eastern Snake River Plain, IdahoA comparative planetary geology guidebook: National Aeronautics and Space Administration, p. 153-163.
King, J.S., 1982, Selected volcanic features of the southcentral snake River Plain, Idaho, in Bonnichsen, B., and Breckenridge, R.M., eds., Cenozoic geology of Idaho: Idaho Bureau of Mines and Geology Bulletin 26, p. 439-451.

[Now the Idaho Geological Survey]

Kuntz, M.A., Champion, D.E., Spiker, E.C., and Lefebvre, R.H., 1986, Contrasting magma types and steady-state, volumepredictable, basaltic volcanism along the Great Rift, Idaho: Geological Society of America Bulletin, v. 97, p. 579-595.

Kuntz, M.A., Covington, H.R., and Schorr, L.J., 1992, An overview of basaltic volcanism of the eastern Snake River Plain, Idaho, in Link, P.K., Kuntz, M.A., and Platt. L.B., eds., Regional geology of eastern Idaho and western Wyoming: Geological Society of America Memoir 179, p. 227-268.

Kuntz, M.A., Skipp, B.A., Champion, D.E., Gans, P.B., VanSistine, D.P., and Snyders, S.R., 2007, Geologic map of the Craters of the Moon $30^{\prime} \times 60^{\prime}$ quadrangle, Idaho: United States Geological Survey Scientific Investigations Map 2969, pamphlet 64 p., 1 sheet, scale 1:100,000. [Also available at https://pubs.usgs.gov/sim/2007/2969/.]

Kuntz, M.A., Spiker, E.C., Rubin, Meyer, Champion, D.E., and Lefebvre, R.H., 1986, Radiocarbon studies of latest Pleistocene and Holocene lava flows of the Snake River Plain, Idaho-Data, lessons, interpretations: Quaternary Research, v. 25, p. 163-176.

Kuntz, M.A., and VanSistine, D.P., 2018, Data release for geologic map of the north half of the Lake Walcott $30^{\prime} \times 60^{\prime}$ quadrangle, Idaho: U.S. Geological Survey data release, https://doi.org/10.5066/F7VQ30VZ.

Malde, H.E., 1968, The catastrophic late Pleistocene Bonneville flood in the Snake River Plain, Idaho: U.S. Geological Survey Professional Paper 596, 68 p.

O'Connor, J.E., 1993, Hydrology, hydraulics, and geomorphology of the Bonneville Flood: Geological Society of America Special Paper 274, 83 p. [Also available at https://pubs.er.usgs.gov/publication/pp596.]

Prinz, M., 1970, Idaho rift system, Snake River Plain, Idaho: Geological Society of America Bulletin, v. 81, p. 941-947.

Putirka, K.D., Kuntz, M.A., Unruh, D.M., and Vaid, N., 2009, Magma evolution and ascent at the Craters of the Moon and neighboring volcanic fields, southern Idaho, USA-Implications for the evolution of polygenetic and monogenetic volcanic fields: Journal of Petrology, v. 50, p. $1639-1665$.

Turrin, B.D., Swisher, C.C., and Deino, A.L., 2010, Mass discrimination monitoring and intercalibration of dual collectors in noble gas mass spectrometer systems: Geochemistry Geophysics Geosystems, v. 11, article no. Q0AA09, accessed 2010 at https://doi.org/10.1029/2009GC003013. 
U.S. Geological Survey Geologic Names Committee, 2010, Divisions of geologic time-Major chronostratigraphic and geochronologic units: U.S. Geological Survey Fact Sheet 2010-3059, 2 p.

Womer, M.B., Greeley, R., and King, J.S., 1982, Phreatic eruptions of the eastern Snake River Plain of Idaho, in Bonnichsen, B., and Breckenridge, R.M., eds., Cenozoic geology of Idaho: Idaho Bureau of Mines and Geology Bulletin 26, p. 453-464. [Now the Idaho Geological Survey.]

For more information concerning this publication, contact: Center Director, USGS Geosciences and Environmental Change Science Center

Box 25046, Mail Stop 980

Denver, CO 80225

(303) 236-5344 


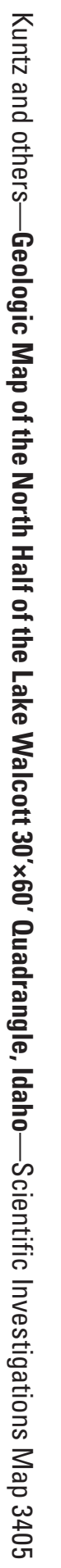

